\title{
1 Sex difference in mate preference based \\ 2 on physical attractiveness in Japan: No 3 longer present or still present?
}

4

5

6

8 Abstract

\author{
Kai Hiraishi*, Ayano Saito, Maki Nishio, Nayu Fujii, and Takato Mori \\ Faculty of Letters, Keio University \\ corresponding author: kaihiraishi@keio.jp
}

Since Buss (1989) initiated research in the field, sex differences in preferences for long-term mates have been extensively studied in evolutionary psychology. Numerous studies have reported robust sex differences such as: 1) a preference for a younger mate is stronger in men than women, 2) a preference for an older mate is stronger in women than men, 3) women value traits associated with resource acquisition, such as economic status and educational attainment, more highly than do men, and 4) men value physical attractiveness more highly than women. However, our replication of Bech-Sørensen \& Pollet (2016) did not to show a significant sex difference in the preference for physical attractiveness among a Japanese sample while the other sex differences (age differences and resource acquisition abilities) were significant (Study 1). We designed study 2 to test if the non-significance was an artifact of the item used to measure the preference for physical attractiveness. Study 2 showed that the sex differences were not statistically significant. In addition, the effect of sex was significantly smaller than the pre-determined smallest effect size of interest (SESOI).

Keywords: Evolutionary psychology, Mate preference, Sex differences, Reviewed pre-registration, replication 


\section{1 配偶者選好における身体的魅力重視度の男女 差は消えたのか.}

3

4 平石界* 斎藤彩乃・西尾眞紀・藤井那侑・森峻人（慶應義塾大学文学部）

$5 \quad$ Corresponding author: kaihiraishi@keio.jp

\section{6 要旨}

7 Buss (1989) 以来、結婚相手に求める特性には性差があることが、進化心理学的視点か 8 ら検討されてきた。それらの研究では一貫して、1）自分より年下の相手を好む傾向は男性

9 の方が高いこと、2）自分より年長の相手を好む傾向は女性の方が高いこと、3）資源獲得 10 能力につながる特性（経済力、学力など）は女性の方が望むこと、4）身体的魅力について 11 は男性の方が望むこと、が見出されてきた。しかし本研究の立案者が日本人サンプルを対象 12 に行った Bech-Sørensen \& Pollet (2016) の追試では、1〜3 は追認されたものの、4につ 13 いては統計的に有意な性差が見出されなかった（研究 1 ）。研究 1 においてこれまで頑健に 14 観察されてきた効果が見られなかったことの理由が質問項目の問題によるものなのか検討す 15 るために行った研究 2 でも、身体的魅力への選好の性差は有意とならなかった。また性差の 16 効果量は事前に設定した Smallest Effect Size of Interest を有意に下回った。 17 18

19 Keywords: 進化心理学、配偶者選好、性差、事前審査付き事前登録、追試 


\section{1 目的}

「配偶」や「婚姻」といった個体間関係は、進化心理学的にみて、非常に重要なもので 3 ある。なぜならば有性生殖する生物にとって、配偶相手を獲得し子孫を残すことができなけ れば、それは生物学的死と（進化の視点からみれば）ほぼ同義だからである。だからと言っ て配偶相手は誰でも良いわけではない。更に、相手に求める特性はさまざまな要因によって 異なってくる。そうした配偶者選好（mate preference）に関わる要因のうち大きな影響力 を持つと考えられているのが生物学的性（biological sex）である。人間の配偶者選好にお ける性差については、Buss (1989)以来、進化心理学的視点からさまざまに検討されてき た。そして結婚相手に求める特性について、1）自分より年下の相手を好む傾向は男性の方 が強いこと、2）自分より年長の相手を好む傾向は女性の方が強いこと、3）資源獲得能力 につながる特性（経済力、学力など）は女性の方が重視すること、4）身体的魅力について は男性の方が重視すること、という性差が頑健であると報告されてきた(Buss \& Schmitt, 2019)。

他方で、家事能力のように、時代と共に選好の性差が小さくなっている特性もある (Buss, Shackelford, Kirkpatrick, \& Larsen, 2001)。このことは、人間の配偶者選好におけ る性差が、必ずしも全ての地域、全ての時代を通じて普遍的なものではないことを示す。こ れまで頑健とされてきた性差（年齢、資源獲能力、身体的魅力）についても、それらが今後 も引き続き頑健であり続ける保証はない。実際、Buss et al. (2001) は、将来の経済的見 込みの重要視における性差が 1939 年から 1996 年にかけて小さくなってきているとも論じ ている。そうであれば、各時代、各地域において配偶者選好にかんする調査を実施しておく ことには一定の意味があるだろう。過去、現在、そして未来のさまざまな地域からのデータ セットを統合して分析することで、人間の配偶者選好の普遍性と状況依存性について、その 要因を含めた分析が可能となるからである。

こうした問題意識から我々は、1990 年代と 2010 年代の米国人サンプルを対象に配偶者 選好の性差を検討した Bech-Sørensen \& Pollet (2016)の追試を、日本人サンプルを対象に Open Science Framework 上に事前登録した上で、2018 年に実施した（研究 1 , https://osf.io/xrgdz）。その結果、年齢差、資源獲得能力について、これまで頑健とされて きた性差が追認された。しかし、Bech-Sørensen \& Pollet (2016)でも、そして米国におけ る 50 年間の変化を追った Buss et al. (2001)でも安定して観察されてきた身体的魅力への 選好における性差は統計的に有意とならなかった。

この結果は、これまで頑健とされてきた身体的魅力への選好の性差が、時代や社会集団 によって変わりうることを意味しているのだろうか。先行する一連の研究と研究 1 のマテリ アルおよび結果を比較する中で、質問項目の wording の問題のために、性差が見出されに くくなっていた可能性が示唆された。そこでこの問題を解決した調査を実施し、配偶者選好 における身体的魅力にかかわる性差が、2010 年代末の日本社会で本当に小さくなっている のか検討した (研究 2 ) 。研究 2 の研究計画は『心理学評論』誌編集委員会における事前審 査を受けて策定した。計画はPsyArxiv 上に事前登録した上でデータ取得ならびに分析を実 施した(Hiraishi, Saito, Nishio, Fujii, \& Mori, 2019)。

以下ではまず、進化心理学的視点からの配偶者選好（mate preference）研究について、 


\section{1 配偶者選好研究}

2 配偶者獲得においてどのような基準が用いられるのか（配偶者選好）という問題は、自

3 然淘汰理論の主要な下位理論の一つである性淘汰理論（sexual selection theory）の枠組み

4 の中で検討されてきた。そもそも性淘汰理論は、有性生殖をする種のオスとメスに大きな形

5 態上、行動上の違い (性差) が見られることへの説明としてダーウィンによって提唱された

6 (Darwin, 1871)。その骨子は、採慨や捕食回避といった生存上の問題だけなく、有性生殖

7 を行う相手 (配偶相手) を選択、獲得する上での有利さもまた、生物の適応上の問題として

8 働くということである。Trivers (1972) は性淘汰理論をより洗練させ、子 1 個体あたりの親

9 の投資（parental investment）の大きな性（多くの場合にはメス）は、より「優れた」配

10 偶者を獲得しようと選択的になると論じた（メスによる選択, female choice）。他方で親

11 の投資が相対的に小さい性においては、より多くの配偶機会を得るべく、同性内での競争が

12 激しくなるとした（intra-sex competition）。この親の投資理論の提唱を受け、主としてヒ

13 卜以外の動物行動研究を対象に、性淘汰のメカニズムと帰結について、さまざまな理論的、

14 実証的研究が展開された(Andersson \& Iwasa, 1996)。

151990 年前後からの進化心理学の展開に伴い、人間行動と心理の理解にも性淘汰理論が応

16 用されるようになった。その嚆矢と言えるのが Buss による 37 文化圈での「理想の結婚相

17 手」に関寸る調査研究であろう(Buss, 1989)。ヒトの子育てには多大な投資が必要である。

18 そのためヒトでは両親が長期的なボンディング（婚姻関係）を形成し、父親も子育てに参加

19 することが、子の生存と成長にとって重要となる(Lovejoy, 1981; Marlowe, 2000)。そこ

20 から Buss は、人間女性は配偶者選択において、子の生存と成長に必要な資源（食料、外敵

21 からの防御など）を提供できる相手を選好するだろうと論じだ。具体的には、経済力や社

22 会的地位、またはそれを求めようとする傾向（野心の大きさや勤勉さ）を重視すると予測し

23 た。調查の結果、将来の経済的見通しの良さを重視する程度については、37 文化圈のうち

2436 文化圈で予測を支持する方向の有意な性差が見られた（ $p$ s <.05）。野心と勤勉さにつ

25 いても、29 の文化圈で予測の方向の性差が見られた。

26 Buss (1989)は、人間の男性にとっては繁殖力（fertility）または繁殖価 (reproductive 27 value) の高い配偶相手を獲得することが重要であるとした。そして女性の繁殖能力

28 (reproductive capacity) は成人後、年齢と共に低下すると論じた上で、男性は配偶相手

29 の若さと、若さと相関する身体的魅力を重視すると予測した。これらについても多くの文化

30 圏から支持的な結果を得た。配偶相手との年齢差については全ての文化圏で男性の方が若い

31 相手を望んでおり、身体的魅力については 34 の文化圈で予測と一致する性差が見られた。

32 後述するように、Buss の研究対象には日本人サンプル $(\mathrm{n}=259)$ も含まれており、その結

33 果は全て予測と一致するものであった。

${ }^{1}$ 本箇所に関連して審查者 1 から、第 2 段階審査の段階で重要な指摘を得た。事前登録 部分に修正を加えることとなるため、編集委員会と協議の上、次の通り脚注にて修正を加え ることとした。「そこから Buss は、ヒトでは両性がともに配偶相手について選択的になる と論じた。ただしその際の選択基準には性差も見られるとした。人間女性は配偶者選択に おいて、子の生存と成長に必要な資源（食料、外敵からの防御など）を提供できる相手を選 好するだろうと論じた。」 
1 Buss (1989)が用いた尺度は Hill (1945)によって開発されたものであり、Hill が報告した 21939 年の米国大学生データ以降、1950 年代、60 年代、70 年代、80 年代、そして 90 年

3 代に渡ってデータが収集されてきていた。Buss et al. (2001)は、約 50 年間で配偶者選好の 4 性差に変化が生じているか検討し、将来の経済的見通し、身体的魅力にかんする性差は、小

5 さくなってきているものの、1990 年代でも依然として頑健であったと報告している。

Buss (1989)に続く形で、Sprecher, Sullivan, \& Hatfield (1994)は米国の全国調査（the National Survey of Families and Households; NSFH）を用いて、12 の特性（5 歳以上年 長、5 歳以上年少、結婚歴、連れ子の有無、職の有無、外見的魅力など）について、それを 持つ相手の結婚相手としての好ましさを 7 段階で尋ねた（Table 1）。18～35 才の未婚者 1329 名（女性 681 名、男性 648 名）の回答を分析した結果、経済力を持つことについて は女性の方が好ましく評価し、外見的魅力や若さを持つことについては男性の方が評価が高 かった。Bech-Sørensen \& Pollet (2016)は、Sprecher et al. (1994) で見られた傾向が 20 年後にも再現されるか検討した。米国のクラウドソーシング・サービスを用いて 2014 年に 集めた 522 名の結果を分析し、経済力、年齢、外見的魅力といった、Buss (1989)で鍵とさ れた特性については 20 年前の結果が再現されたことを報告している（Table 1）。

また最近では、Zhang, Lee, DeBruine, \& Jones (2019)が、2011〜2018 年のあいだに 36 文化圈でBuss (1989)の項目を用いて行われた調査をまとめている。彼らは社会におけ る男女平等性が高い場合に、配偶者選好における性差が小さくなるか検討したが、そうした 傾向は有意とならなかった。身体的魅力にかんする性差も、資源獲得力にかんする性差と同 様、頑健であった。

\section{研究 1}

22 目的

研究 1 は、現代日本において、従来語られてきたような配偶者選好の性差が見られるの か検討するために、Sprecher et al. (1994) および Bech-Sørensen \& Pollet (2016)で用い られた尺度を用いた事前登録付き追試を 2018 年に実施した（https://osf.io/xrgdz）。Buss (1989)ではなく、Sprecher et al. (1994) と Bech-Sørensen \& Pollet (2016)の追試を行っ たのは、後者の質問項目が進化心理学の視点から重要とされてきた年齢差、経済力、身体的 魅力といった配偶者選択における特性をカバーしていること、そして Buss (1989)で用いた 質問票に比べ、質問項目が洗練されていると考えたためであった。

Buss (1989)の用いた尺度は、18 の特性について、結婚相手にどれほど重要と考えるか 0 〜3 点の 4 段階で回答するものであった。回答選択肢には”Irrelevant or unimportant” (0 点）、”Desirable, but not very important”（1 点）といったラベルが貼られており、その 意味するところが必ずしも明確でなく、また回答は中立点にたいして対称とはなっていなか った。18の特性記述には”Good cook, housekeeper”、”Ambition, industriousness”など ダブルバレルとなっているものが少なくなかった（尺度の詳細な内容は Boxer, Noonan, \& 36 Whelan (2013)に詳しい)。これに対して Sprecher et al. (1994)の尺度は標準的な 7 件法 
1 ここでBuss (1989)が用いた尺度と、研究 1 で用いた Sprecher et al. (1994)の尺度で

2 は、身体的魅力に関わる項目に大きな違いがあったことを指摘しておきたい。Buss (1989)

3 の尺度における当該の項目は Good look（容姿が良い）であり、そのことの重要性を尋ね

4 る形となっていた。それに対して Sprecher et al. (1994)の尺度での項目は not "good-

5 looking”であり、そうした対象の結婚相手としての好ましさを回答する形となっていた

（項目にはダブルクオテーションが含まれていた）。すなわち後者では身体的魅力にかかわ

7 る質問は逆転項目となっていた。

研究 1 の実施にあたって、まず予備調査を行った（研究 1 予備調査）。その結果を受 け、質問項目の見直しと例数設計を行い本調査を行った（研究 1 本調査）。

\section{0 方法}

\section{1 参加者}

12 Just Systems 社の提供するWeb 調査サービス（Fastask, fast-ask.com）を用い同サー 13 ビスの登録モニタから 18〜35才の未婚の男女を対象に予備調査を実施した。設問数に対

14 し、Fastask での実施最低金額（1 万円）で集められる最大のサンプルサイズであった男女 15166 名ずつ合計 332 名を回収目標值に設定した。最終的に 367 名が参加したが、このうち 1618 名が事前説明（後述）を読んだ後に回答から離脱したので、最終的な回答者は女性 153 名、男性 161 名の合計 314 名であった（平均 28.04 才， $S D=4.70$ ）。

予備調査の結果を踏まえて、同じくFastaskを用いて本調査を行った。未婚で子供のい ない 18３5 才の男女 250 名ずつ 500 名を募集に回答者を募集した。本調査のサンプルサ イズは、予備調查で得られた身体的魅力にかんする項目（項目 10）での性差の効果量を根 拠に算出したが、計算方法に間違いがあったため、適切な例数設計ではなかった ${ }^{2}$ 。具体的 には、項目 10 の効果量の信頼区間の下限 $g=-0.44$ を基準に、有意水準 サイズとして各群 189 名、合計 378 名の回答が必要と計算した。予備調査において参加同 意質問について拒否を選択した参加者が一定数いることを見込み、余裕をみて男女各 250 名、計 500 人を目標に設定した。しかし検定力分析においては、効果量の点推定值である0.22 を採用寸る方が妥当であった。

28 参加者は 552 名であったが、66 名が事前説明後に回答から離脱したので、最終的な回答 者数は女性 229 名、男性 257 名の計 486 名であった（平均 28.09 才, $S D=4.92 ） 。$

${ }^{2}$ 本箇所に関連して第 2 段階審査において審査者 1 から、例数設計の根拠について、説明 を追加したほうが良いのではないか、との示唆を得た。事前登録部分に修正を加えることと なるため、編集委員会と協議の上、次の通り脚注にて修正を行うこととした。「予備調査に おいて、予想に反して身体的魅力にかんする項目（項目 10）において性差が有意とならな かったため、この点を確認することを念頭に本調査の例数設計を行った。すなわち項目 10 での性差の効果量を根拠に必要サンプルサイズを算出した。しかし計算方法に間違いがあっ たため、適切な例数設計ではなかった。」 
予備調査で回答した Fastask の登録者には、本調査での回答依頼を送信しなかった。そ のため 2 つ調査の回答者は、Fastask の規定に反し二重登録をしている者がいる場合を除 き、重複していない。全ての参加者は、事前説明で参加拒否を選択した者も含め、Fastask の規定にもとづき同社から謝礼が支払われた。

\section{調査内容}

Sprecher et al. (1994)ならびに Bech-Sørensen \& Pollet（2016)が用いた 12 の特性に 関して結婚相手としての望ましさを尋ねる尺度を日本語に翻訳して用いた（Table 1）。研 究 1 予備調查と研究 1 本調查では質問項目に違いがあった。予備調查では項目 10 の not “good-looking”を「容姿が良くはない」とした（実際の調査では下線による強調は含まれ なかった）。予測に反しこの項目の性差が有意とならなかったため、改めて翻訳について日 英バイリンガル話者と相談し、本調查では「容姿が良くない」と変更した。また本調査では 12 項目に加え、探索的な項目として「自分は相手に対しての愛情を持っているが、相手は 自分に対しての愛情を持っていない」と「自分は相手に対しての愛情を持っていないが、相 手は自分に対しての愛情を持っている」の 2 項目を尺度の末尾に追加した（この 2 項目の 結果については今回は報告しない）。

Fastask からの要求により、12 項目への回答の前に、結婚相手への好みに関して宗教や 人種にかんする質問が含まれることを伝えた上で調査参加の同意を得た。既述の通り、この 段階で一定数の回答離脱者があった。

Sprecher et al. (1994)ならびに Bech-Sørensen \& Pollet (2016)では長期的関係におけ る結婚の重要性にかんする項目も尋㸚ていた。しかし配偶者選好にかんする 12 項目への調 整効果がほとんど見られていなかったこともあり、本研究では省略した。

Fastask の登録情報から、回答者の年齢、性別、居住都道府県および職業の情報が、設 問への回答とともに提供された。このうち性別を分析に用いた。

本調査の実施にあたり、慶應義塾大学文学部研究倫理委員会に研究倫理審査を受け承認 を得た（承認番号 160190003）。

\section{結果}

\section{予備調查}

12 の特性のうち 8 の特性について、Welch の検定により性差が 5\%水準で有意となった (Table 2)。年齢に関する 2 つ項目については、相手が自分より若いことを好む傾向は 男性の方が、自分より年長であることを好む傾向は女性の方が強かった。収入にかんする 2 つの項目では、女性の方が自分より収入の低い相手を好まず、収入の高い相手を好む傾向が 見られた。同様に、女性の方が自分より学歴の低い相手を好まず、学歴の高い相手を好む傾 向が見られた。また、定職に就きそうにないことは、女性の方が否定的に評価していた。こ れらは Sprecher et al. (1994)、Bech-Sørensen \& Pollet (2016)と合致するものであった

(Table 1)。宗教が異なることについては、2つの先行研究では性差が有意でなかった が、日本における予備調査では女性の方が否定的な性差が有意であった。これらの性差は Bonferroni 法で有意水準を 0.00417 (=0.05/12) に調整した場合であっても有意であっ 
1 た。性差が有意とならなかった 4 項目は、離婚歴、子供の存在、人種、そして容姿であっ

2 た。

\section{3 本調査}

12 の特性のうち 10 の特性について、Welch の検定により性差が $5 \%$ 水準で有意となっ た（Table 2)。年齢、収入、学歴、そして定職にかんする項目については予備調査を追認 する結果であった。すなわち、年齢が上であること、収入が高いこと、学歴が高いことは女 性の方が好意的に評価する一方、年齢が下であること、収入が低いこと、学歴が低いこと、 そして定職に就きそうにないことは、女性の方が否定的に評価していた。宗教が異なること について女性の方が否定的であることも予備調查の結果を追認するものであった。子供の存 在については、女性の方が否定的な評価をしており、先行研究とは逆の方向であった。性差 が有意とならなかったのは人種、容姿の 2 項目であった。離婚歴については女性の方が否 定的な方向で有意であったが、Bonferroni 法で調整した場合には有意でなかった（ $p$ $=.015>.00417)$ 。

\section{4 考察}

研究 1 の結果は、Buss (1989)の進化心理学的予測にかかわる主要な点においては Sprecher et al. (1994) ならびに Bech-Sørensen \& Pollet (2016) を追認するものであった (Table 2)。すなわち男性の方が若さを好み、女性の方が経済力や地位を好む傾向が確認 された。

19 しかし先行研究との重大な違いが見られた。それが身体的魅力への評価に統計的に有意 な性差が見られなかったことである。男性の方が配偶相手の身体的魅力を高く評価する傾向 があることは、Buss (1989) 以来、繰り返し報告されてきた。Buss et al. (2001)による北米 における 50 年間の変化を追った研究でも、性差が小さくなる傾向は見られたものの、 1990 年代には依然として統計的に有意な性差が報告されていた。研究 1 の直接的な先行研 究となる Bech-Sørensen \& Pollet (2016)でも、2010 年代の米国サンプルにおいて性差が 見られたことが報告されている。Zhang et al. (2019)も、2010 年代の 36 力国における調 査において性差が頑健であったとを報告している。これに対し研究 1 では、先行研究と同 じ方向の差は見られたが、予備調查、本調查を通じてその効果量は小さく（予備調査, $d=$ $-0.22[0.00,-0.44]$; 本調查 $d=-0.10$ [0.08, -0.28]）、統計的にも有意でなかった。

「男性の方が身体的魅力を重視する」という言説は、Buss の進化心理学的理論における 中核的主張の 1 つであり（Buss \& Schmitt, 2019）、また Buss の理論は別としても、長期 に渡って多地域から頑健に報告されてきた傾向である。実際、Buss (1989)で報告されてい る日本人サンプル 265 名の分析結果においても Good looks 項目の性差は有意であった

(Buss, 1989, p.10, 男性平均 $=1.50(S D=0.75)$, 女性平均 $=1.09(S D=.74), t(257)=$ $344.36, p=.000$, Hedge’s $g=0.55)$ 。それゆえ研究 1 で予備調查と本調査を合わせて 800 名以上の日本人データを収集した結果、性差が有意とならなかったことは注目に值する。し かし、後述するように、一連の先行研究における結果と、研究 1 における結果を比較する 中で、質問内容の文言が回答に影響する可能性が考えられた。また先述したように研究 1 の本調査における例数設計にも問題があった。これらの点を受け、2010 年代末の日本人サ 
1 ンプルにおいて、結婚相手における身体的魅力への選好の性差が小さくなっていると言える

2 のか、より念入りに確認するために研究 2 を実施した。

\section{3 研究 2}

4 目的

Bech-Sørensen \& Pollet (2016)では身体的魅力の望ましさを尋ねる項目として Was not “good looking”が用いられていた。これを受け、研究 1 の予備調査では 容姿が良くは年ない という項目を用いた。その結果、予想に反し性差が見られなかったため、研究 1 本調査で は容姿が良くないを用いた（調査の際には下線による強調はなされていない）。本調査に おいても性差は見られず、予備調査とほぼ同様の得点を示した（Table 1）。

ここで Sprecher et al. (1994)ならびに Bech-Sørensen \& Pollet (2016)における、身体 的魅力項目一回答得点を見ると興味深いことに気づく（Table 1）。回答は、1 点（全く望 ましくない）～7 点（非常に望ましい）の 7 段階でなされていたが、2つの先行研究におけ る男性回答者の平均はそれぞれ 3.41 と 3.71 であった。すなわち中立（4 点）を僅かに下 回っていた。他方で女性の平均は 4.42 と 4.34 であり、僅かであるが、中立よりも好まし い方向に評価されていた。つまり先行研究の女性回答者には、容姿に優れない相手を好まし く評価する傾向が伺えた。一方で研究 1 の女性回答者の平均は予備調査で 3.49、本調査で 3.45 であり、いずれも中立を下回っていた。男性平均は予備調査で 3.22 、本調査 3.32 で あった。米国での 2 つの先行研究と比べ、男女ともに平均得点は下がっていたが、女性に おける低下がより目立ったことが、研究 1 において性差が縮まった原因と捉えることがで きる。

2 つの先行研究の女性回答者に not “good-looking” な異性をむしろ好意的に評価する傾 向が見られた理由は明らかではない。もしも good-looking な男性として一般にイメージさ れるのが男性的な風貌であるならば、そうした風貌と結び付けられやすいとされる支配的パ ーソナリティを避けようとしたのかもしれない(Penton-Voak et al., 1999)。ただ他方で、 複数の相手との短期的な配偶関係を指向する男性の顔の魅力度は、低く評定されるという報 告もある(Boothroyd, Cross, Gray, Coombes, \& Gregson-Curtis, 2011 ; Boothroyd, Jones, Burt, DeBruine, \& Perrett, 2008)。つまり男性の容姿の魅力度は、女性が一般に求 めるとされている性質（安定した長期的な配偶関係をもつ傾向）と正に相関していることと なり、女性が not good-looking な男性を敢えて好意的に評価する理由はないこととなる。

米国における 2 つ先行研究に見られたパターンが生じた理由は不明である。しかしこ れらの結果は、容姿の良さを好むことと、容姿が良くないことを厭うこととは、必ずしも同 義でないことを示唆している。なぜなら Buss et al. (2001)やZhang et al. (2019)が報告し ているように、Good look 項目、すなわち容姿の良さへの選好を順項目で問う場合におい て米国人サンプルは、（性差はあるものの）男女共に一貫してポジティブな回答を与えてき たからである。

以上の考察から、日本人サンプルを用いた研究 1 において性差が有意とならなかった理 由として、容姿の良さへの選好を逆転項目で尋ねたことが影響した可能性を考えた。従来一 
1 て、現在の日本では性差が縮小したと結論付けるのは性急であろう。そこで研究 2 におい

2 ては、Buss (1989)に倣う形で、容姿への選好を順項目で尋ねる調查を実施した。その場合

3 でも性差が縮小していれば、現在の日本社会において、他の時代、地域とは異なり、結婚相

4 手の容姿への選好における性差が小さくなっていると結論づけることが可能となると考え

5 た。

\section{6 方法}

\section{7 調査手続き}

調査計画は『心理学評論』誌における審査をへて策定され、2019 年 6 月 25 日に

9 PsyArxiv 上に事前登録された(Hiraishi et al., 2019)。慶應義塾大学文学部研究倫理委員会

10 における承認（2019 年 7 月 22 日、承認番号 160190004）を経て、Just System 社の提供 11 するWeb 調査サービス（Fastask, fast-ask.com）を用いて実施した（調査期間 : 2019 年

127 月 25 日〜 7 月 31 日)。

\section{3 主たる目的変数とその測定方法}

研究 2 の中心となる目的変数は、身体的魅力の高い対象にたいする、結婚相手としての 好ましさ評価であった。すなわち研究 1 の「容姿がよくない（よくはない）」という項目 10 を「容姿が良い」に変更した。説明変数は回答者の性別であった。Sprecher et al. 究 1 で用いた他の 11 の特性についても回答を求めた。研究 1 本調査で探索的目的から追加 した 2 つの項目（「自分は相手に対しての愛情を持っているが、相手は自分に対しての愛

20 情を持っていない」と「自分は相手に対しての愛情を持っていないが、相手は自分に対して の愛情を持っている」) は用いなかった。

回答者には最初に、結婚相手としての好ましさにかんする質問を行うこと、その中に宗 教や人種にかかわる質問が含まれること、また性的指向について回答を求めること、調査は 学術目的であることを通知し、承諾を得た。その後、性的指向（sexual orientation、異性 愛指向、同性愛指向）を確認寸る質問を新たに追加した。Boothroyd et al. (2009)に倣い 1 点=完全に同性愛指向から 7 点=完全に異性愛指向の 7 件法の Likert スケールで性的指向を 尋ねた。Fastask との協議を経て、中点である４点に「どちらともいえない／わからない／ あてはまるものはない」というラベルを付した。また、性的指向質問において 4 点以下を選 択した回答者は、その時点で回答を終了することにした。日本国において 2019 年 7 月時点 で同性間での法律婚は不可能であり、回答者は日本国内在住者に限られていたため、同性愛 指向の回答者に結婚相手としての望ましさを尋ねることの難しさが Fastaskより指摘され た。当初より性的指向質問で 4 点以下の回答者のデータは除外する計画であったため、回 答自体をこの時点で終了することとした。性的指向質問を含めるにあたって、調查が学術目 的であることを冒頭で明示するよう Fastaskより求められたので、これに対応した。

Fastask にモニタ情報として登録されている回答者の年齢、性別、婚姻状態、子供の有 36 無、職業、居住地（都道府県）の情報提供を受けた。このうち性別と年齢のデータを分析に 37 用いた。 


\section{1 主たる分析方針}

事前計画から分析方針に変更はなかった。身体的魅力に関する項目において性差が見ら れるかWelchの検定を行った。他の 11 項目についての検定は行わず、参考のために性差 の効果量ならびにその 95\%信頼区間を求めた（Table 4）。単項目からなる尺度のため、， ンパラメトリックな方法（例えば Brunner-Munzel 検定）を用いる方が妥当であるとこ ろ、Welch の検定を用いた理由は 2 つである。第 1 に、Buss (1989)以来の研究はいずれも 男女の平均值の差を検討してきた。Brunner-Munzel 検定は平均順位の検定を行うものであ り、先行研究との連続性を担保するという面で不利である。第 2 に、ノンパラメトリック 検定の検定力分析と、それによる例数設計の方法が、我々が調べた限りにおいては、確立さ れていなかった。Welch 検定に加えて Brunner-Munzel 検定も行うこととし、Bonferroni 法によって有意水準を $5 \%$ の $1 / 2$ の 2.5\%に調整することも可能ではある。しかし研究 2 の 目的が、日本における性差の縮小が確実であるか検討することにある点を考えると、検定回 数を増やして有意水準を低く設定することは、むしろ予測方向に結果を誘導する恐れがあ る。以上を鑑みて、研究 2 では「容姿が良い」項目の Welch 検定だけを $5 \%$ 水準で行う計 画とした。

通常のWelch の検定に加えて「容姿が良い」項目に対しては、 $d=0.26$ をSESOI (Smallest Effect Size of Interest) とした inferiority test を行った(Lakens, Scheel, \& Isager, 2018)。すなわち効果量 $d$ がどんなに小さくても 0.26 であることを帰無仮説 HO と し、 $d$ が 0.26 より小さいことを対立仮説 $\mathrm{H} 1$ とした Welch の検定を行った。帰無仮説が棄

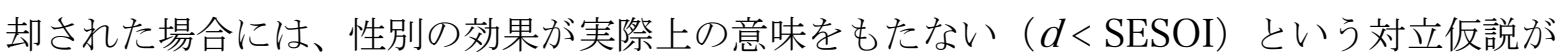
採用される。SESOI として $d=0.26$ を採用したのは、直接の先行研究である BechSørensen \& Pollet (2016)における身体的魅力項目における性差の効果量の 95\%信頼区間 の下限が 0.26 であったことによる。Bech-Sørensen \& Pollet (2016)の先行研究である Sprecher et al. (1994)では効果量の 95\%信頼区間下限は 0.61 であった。また、Buss et al. (2001)は、1930 年代末から 1990 年代までの 50 年間で身体的魅力への選好の性差は縮 小方向にあると報告しているが、その時点での最新である 1996 年のデータでも効果量は概 ね 0.7 であった。2010 年代に 36 カ国で収集されたデータを集計した Zhang et al. (2019) が Open Science Framework で報告している平均值と標準偏差から、最もサンプルサイズ の大きかった米国（女性 1142 名、男性 364 名）での効果量を計算したところ 0.53 であっ た（https://osf.io/3cjwm/）。以上から、性差の効果量 $d$ が 0.26 を超えることがないので あれば、十分に小さいと言えると考えた。

\section{追加的な分析}

追加的分析についても、事前登録から大きな変更はなかった。各 12 項目について、研究 1 予備調查、本調査、ならびに研究 2 から得られた性差の効果量を統合した重み付け平均効 果量を求めた（メタ分析）。対象となる研究が 3 つと少ないことから、固定効果モデルを 用いる計画とした。後述するように、効果量の等質性が疑われた項目については変量効果モ デルの結果も参考として併記した。身体的魅力項目については、研究 2 の得点を逆転した 上で効果量を統合した。

参加者の年齢と各 12 項目の得点の相関係数を男女別に報告した。結婚相手に求める特性 は年齢ごとに変化するかも知れない。例えばBuss (1989)の議論に従えば、10 代後半の男 
1 性にとっては、自らより年齢の高い女性の方が、直近の fertility は高いことになる。他方で 230 代の男性にとっては、自らより年齢の低い女性の方が高い fertility を持つことになる。

3 更に年齢の上昇とともに結婚相手に求める特性はより大きくなるのか探索的に検討した。参

4 加者ごとに、各項目得点と 4 点（中立点）との差の絶対值を合計したものを求め、その得

5 点と年齢との相関係数を男女別に求め報告した。なお、研究 1 の予備調查ならびに本調査

6 における同様の分析結果は Table 3 にまとめた。

\section{7 調査対象}

8 研究 1 に引き続き、Just Systems 社が提供する Web 調査サービス（Fastask）を用い

9 た。Web 調査サービスの回答者の質は、クラウドソーシングサービスのそれと比較して劣

10 るという報告がある(三浦・小林, 2015)。しかし研究 1 においては、身体的魅力にかんする

11 項目の他は、基本的に先行研究を追認し、理論的に予測される結果が得られていた。本研究

12 で扱う問題について、Fastask 経由での回答者が特別な偏りを持っていたと考える理由は見

13 当たらない。他方でクラウドソーシングを用いた場合には、性別や年齢層を事前に指定して

14 回答者を集めるのが難しい。我々がクラウドワークス（Crowdworks.jp）を用いた経験か

15 らは、回答者が女性に偏る傾向も見られた。これらの事情のために例数設計にもとづいて男

16 女同数のサンプルを集めることに困難が伴うと予想された。各群の人数がアンバランスとな ったときに、どこまでのサンプルを分析に用いるかを事前に決定することは困難であり、他 方で事後的に決定すれば恣意的となってしまう。各群の人数が事前の計画を上回るまでサン プル回収を続けた上で、多い方の群からランダムにサンプリングすることで各群の人数比を 揃えることも可能だが、回答者数に大きな偏りがあった場合、研究実施上および社会的コス トが大きなものとなる（査読者 2 によるコント）。以上を鑑みて、参加者の属性（婚姻状 況、子供の有無、年齢、性別）を指定しての回答者募集が確実に行えるWeb 調査サービス を用いることとした。

本研究の主目的は、身体的魅力にかんする性差が日本社会で見られなくなっているか検 討することであった。そこで例数設計には、上述したSESOI を $d=0.26$ とした Inferiority test において、有意水準 5\%のとき $80 \%$ の検定力を持つサンプルサイズとして、各群にお ける $n=254 （ N=508 ）$ を採用した。検定力の計算は Lakens (2016)が紹介する spreadsheetを用いた（https://osf.io/qzjaj）。

事前説明の段階で回答を取りやめる参加者が一定する発生することを見込む必要があっ た。研究 1 本調查ではその数は 552 名中 66 名（約 $12 \%$ ）であった。同程度の離脱が生じ ると見込むと、男女各群で 289 名の参加者を確保する必要があると推測した。さらに余裕 を見て男女各 300 名、合計 600 名の回答を募集する計画を立てた。研究 1 と同様、18３5 歳、未婚、子供がいないことを参加条件とした。なお Fastask の調査では、予定人数より多 く（最大で $10 \%$ 程度）の回答を得られることがあるが、その場合には全ての回答を分析対 象とする計画として調査を実施した。研究 1 の参加者は募集対象から除外した。

最終的には 661 名が調查に参加した。このうち 45 名 (6.8\%) が事前説明の段階で調査 から離脱した。残る 616 名のうち 113 名 (18.3\%) が性的指向にかんする質問で中点（4 点）以下を選択し、調査から離脱した。そのため分析対象となる回答者数は女性 259 名 39 (平均 27.16 才, $S D=4.71$ ) 、男性 244 名（平均 28.04 才, $S D=4.68$ ） となった（全参 加者の 76\%）。計画では各群 254 名を予定していたが、その 95\%（241 名）を上回るデー 
1 タが収集できたので、サンプル追加は行わず、この 503 名を対象として分析を行った。こ 2 の判断については『心理学評論』編集委員に連絡の上で決定した（三浦麻子, 2019 年 7 月 329 日私信）。

\section{4 結果}

\section{5 身体的魅力項目}

身体的魅力にかんする「容姿が良い」項目の回答得点に性差が見られるか、性差が無い ことを帰無仮説とした Welch の検定を行った。先行研究からは男性の平均点の方が高いこ とが予想された。男性平均 5.29 点、女性平均 5.20 点で、性差は予想と同じ方向であった

9 が、検定の結果は有意でなかった $(t(493)=0.68, p=.50$, Hedge’s $g=0.06[-0.12$,

$100.24] ） 。$ 同項目について効果量 0.26 をSESOI とした inferiority test を行ったところ有意 11 であった。すなわち効果量が 0.26 を上回るという帰無仮説が棄却された $(t(493)=-2.24$, $12 p=.013)$ 。なお inferiority test は R (R core team, 2018) の TOSTER パッケージ

13 (Lakens, 2017)に含まれる dataTOSTtwo 関数を用い、効果量の上限值 0.26 にたいする検 14 定結果を参照した。

\section{全項目の傾向}

研究 2 における全 12 項目の男女平均值ならびに性差の効果量を表 4 に示した。また研 究 1 予備調查、本調査、研究 2 で得られた各項目における性差の効果量を、固定効果モデル を用いて統合した、重夕付け平均効果量を求めた（Figure 1A，1B）。なお「定職に就きそ うにない」（項目 5）および「自分よりはるかに収入が高い」（項目 9）については、効果 量の等質性の検定が $5 \%$ 水準で有意であったため、変量効果モデルによる結果も提示した

(Figure 1C)。身体的魅力項目については、研究 1 と研究 2 で質問の方向が異なるため、 研究 2 の効果量を逆転した上で統合した上で、変量効果モデルの結果も求めた（Figure 1C)。

Buss(1989)以来の進化心理学的予測に関わる項目については、予測を指示する方向の性 差が示された。すなわち、年齢が上であること、収入が高いこと、学歴が高いことについ て、重み付けされた平均効果量の 95\%信頼区間は 0 をまたがず負となり、女性の方がこれ らの項目で高得点であったことが示された。一方で、年齢が下であること、収入が低いこ と、学歴が低いこと、そして定職に就きそうにないことの平均効果量は正となり、男性の方 が高得点であったことが示された。項目 5 (定職) ならびに項目 9 (高い収入) について、 固定効果モデルと変量効果モデルで大きな違いは見られなかった。

身体的魅力にかんする項目についても、平均効果量の信頼区間は 0 をまたがず負となっ た。つまり、容姿が良くないことについては男性の方が低評価（容姿が良いことについては 男性の方が高評価）であった。ただし信頼区間の下限の絶対值は 0.22 であり、研究 2 の計 画時に設定した SESOI = 0.26 を下回った。変量効果モデルでも結果は同様であった。

進化心理学的予測と直接には関わらない項目については、3つの調查で比較的類似した 結果が得られた。既婚歴、子持ちであること、宗教が異なることの 3 項目については、いず 
1 査ならびに研究 2 では正の効果となり、調査ごとの違いが見られた。もっとも、いずれも信

2 頼区間は 0 をまたいでおり、また効果量の等質性検定は有意でなかった $\left(I^{2}=.05\right.$

$3[.00, .90], p=.35)$ 。重夕付け平均効果量についても、12 項目のうちで唯一信頼区間が 0

4 をまたぐ結果となった。

\section{5 年齢と選好の関係}

6 各項目における回答得点と年齢の相関を、男女別に求めた（Table 5）。相関係数の

$795 \%$ 信頼区間が 0 をまたがなかったのは、男性参加者における「5 才以上若い」項目だけ

8 であった $(r=.14[.02, .26])$ 。他の項目についても相関係数は 0.1 未満のものが大半であ

9 り、0.2 を超えるものは少数しかみられなかった。

\section{0 考察}

\section{1 身体的魅力への選好}

研究 2 では身体的魅力への選好を順項目「容姿が良い」を用いて尋ねた。性差が無いこ とを帰無仮説とした Welch 検定の結果は有意でなかった。意味のある最小の効果量

（Smallest Effect Size of Interest）を $d=0.26$ （男性 > 女性）に設定した inferiority test は有意であり、本研究で設定した基準にもとづいて、研究 2 で観察された性差は、実質的な 意味のないものと判断された。研究 1 と研究 2 のメタ分析により得た平均効果量の 95\%信 頼区間は 0 をまたがなかった（Figure 1B, -0.11 [-0.22, 0.00]）。他方で研究 2 の inferiority test のために設定したSESOI $(d=0.26)$ を下回っていた。このSESOI をメタ分 析の結果の解釈に用いることは事後的な判断となるが、現代日本において、身体的魅力への 選好にかんして、性差が縮小していることを示すものと言えるだろう

興味深いことに、順項目を用いた研究 2 において、男女の平均值はそれぞれ 5 点台とな り、 7 段階評価の中点（4 点）よりも 1 点以上外れていた。他方で研究 1 での男女平均值は それぞれ 3 点台であり、中点からのずれは 1 点未満であった。容姿が良くないことを厭う程 度と、容姿が良いことを好む程度には、違いのあることが示唆される。他方で、いずれの場 合でも性差の大きさ (効果量) には大きな違いは見られなかった。

身体的魅力の他の、進化心理学的に重要とされる特徵については、研究 2 の結果、研究 281 と 2 をあわせたメタ分析の結果いずれにおいても、全て先行研究と一致する、仮説を支持 する方向の性差が観察された。すなわち、資源獲得力と関連すると考えられる特徽（年長で あること、高い収入、高(学歴）については女性の方が好む傾向が見られた。また、資源獲 得力の低さを示寸特徵（定職に就きそうにないこと、低い収入、低い学歴）については、女 性の方が低い評価をつけていた。繁殖力（fertility）や繁殖価（reproductive value）と相 関するとされる若さについては、男性の方が高い評価を与えていた。なお年龄については女 性の繁殖価と負に相関すると同時に、男性の資源獲得力とは正に相関する。男性の「自分よ り 5 才以上年上」である結婚相手への得点が 7 段階評価の中点（4 点）を下回る一方で、女 36 性のそれが 4 点を上回ったこと、その逆に「自分より 5 才以上年下」な相手への評価は、男 


\section{1 年齢と選好の関係}

各項目における回答と、回答者の年齢の相関について探索的に検討したが、特に意味の

3 ある関係は見いだされなかった。

\section{4 総合考察}

配偶相手にどのような特性を求めるかという問題は、1990 年代前後の進化心理学の興隆 初期から大きな関心を集めてきた。特に長期的な配偶相手（例えば結婚相手）を選ぶにあた って相手に求める特性には、進化的に予測できる性差があると論じられてきた(Buss \& Schmitt, 1993, 2019)。男性は相手の繁殖価や繁殖力と相関する特性である若さや身体的魅 力を重視する一方、女性は相手の資源提供力と相関する特性である経済力、学歴などといっ た社会経済的地位を重視するというのがその中心的な主張である。研究 1 では、12 の特性

（うち進化心理学に関連するものは 8 特性）について、結婚相手としての望ましさを尋㸚 た Bech-Sørensen \& Pollet (2016)の直接的追試を行った。その結果、年齢差、経済力、学 歴などに関しては仮説を支持する、先行研究と一致した性差が観察された。しかし身体的魅 力への選好への性差は有意とならず、仮説を支持しなかった。研究 2 では、身体的魅力に関 わる項目を「容姿がよくない」から「容姿が良い」へと変更した。その場合でも性差は有意 とならなかった。また性差の効果量は、事前に設定した実質的に意味のある最小効果量 查、研究 2 のメタ分析によって統合した効果量の 95\%信頼区間上限も、SESOI $(d=$

19 0.26）を下回っていた。以上の結果から、2010 年代末の日本において、身体的魅力への選 20 好に関する性差は縮小していることが示された。

\section{なぜ身体的魅力への選好の性差は縮小したのか}

性差が縮小した理由について、本研究のデータから直接の回答を得ることはできない。 まず本研究に方法上の問題がなかったか検討しておく必要がある。第一に、Likert 法を用い たことの限界が指摘できる。各特性について別個に望ましさを尋ねるため、全ての特性につ いて非常に望ましいと回答することも可能であった。特性間での順位付けを求めれば性差が 見られるかもしれない(Li, Kenrick, Bailey, \& Linsenmeier, 2002)。しかし他の進化心理学 関連の特性で性差が頑健であった中、なぜ身体的魅力についてだけ Likert 法を用いた時に 性差が縮小したのかは、依然として不明である。サンプルに偏りがあった可能性も指摘でき る。先行研究である Sprecher et al. (1994)は全国調査であり、Bech-Sørensen \& Pollet (2016)はクラウドソーシングによる調査であった。本研究が用いた Web 調査サービスの登 録モニタとはサンプルの性質が異なったことは否定できない。しかし、なぜ身体的魅力項目 だけが、今まで頑健に報告されてきたパタンを再現しなかったのか、疑問は残る。

第三に、「容姿が良い/よくない」という表現の問題を検討したい。「容姿」には、体 つきや顔つきなど個人の生物学的特性を反映する面と、化粧、髪型、服装など個人のパーソ ナリティや社会的地位などを反映する面が含まれうる。女性回答者が後者を「容姿」という 表現に読み取り、その重要性を高く評価した可能性がある。言い方を変えれば、現代日本社 会では、（特に男性の）容姿が社会的地位を反映するシグナルとして用いられている可能性 である。第 2 查読者より、各項目への回答の相関から、この可能性が検討できるのではな 
1 いかとの示唆を得た。研究 2 において「容姿が良い」と「収入が高い」の相関を見たとこ

2 万、女性で $\tau=.52,95 \%$ CI [.42, .62]、男性で $\tau=.35,95 \%$ CI [.22, .46]と、女性において

3 より大きな相関が見られた。同様に「容姿が良い」と「学歴が高い」の相関も女性で

$4 \tau=.50,95 \%$ CI $[.39, .58]$ 、男性で $\tau=.38,95 \%$ CI [.28, .47]であった（Supplementary

5 Information）。これらは上述の可能性を支持寸る結果であった。しかし研究 1 における

6 「容姿がよく（は）ない」と収入、学歴にかんする項目との相関を見ると、結果は必ずしも

7 一貫しない。例えば研究 1 本調査における「容姿がよくない」と「収入が低い」の相関のよ

8 うに、男性の方が相関の大きい場合も見られた（女性 $\tau=.26,95 \%$ CI $[.14, .38]$ 、男性

$9 \tau=.36,95 \%$ CI $[.25, .47]) 。$

10 もっとも、何をもって容姿が良いとするか、男女回答者の理解が異なっていたことは、 十分に考えられる。研究 2 において、男性回答者では「容姿が良い」と、繁殖力と関係する とされる「自分より年少」への項目が正に相関していた。一方で、女性回答者では、資源獲 13 得力と関連するとされる「自分より年長」との間で正に相関していた。身体的魅力への選好 14 の程度に性差は見られなかったが、その適応上の意味は男女で異なっている可能性は高いだ 15 ろう。今後の検討が求められる。

以上を鑑みた上で、仮に、実際に現代日本社会で性差が縮小していたとして、その理由 について本研究から論じられることは、残念ながらほとんどない。時代や地域など、社会集 団によって配偶選好の性差が異なる理由として、Eagly \& Wood (1999)は社会のジェンダ 一平等度が低いほど、配偶者選好の性差が大きくなる可能性を指摘している。彼女らは Buss et al. (1990)のデータを分析し、経済力などへの選好にかんする性差とジェンダー平 等度に関連があると指摘している。しかし身体的魅力への選好については、関連が見られな かったとも述べている。Eagly \& Wood (1999)を受けて最近、Zhang et al. (2019)が、 2010 年代に諸地域で行われた配偶選好調査のマルチレベル分析からジェンダー平等度の影 響を検討したが、身体的魅力への選好にかかわる性差には、ジェンダー平等度がほぼ関連し ていなかったと報告している。社会のジェンダー平等度が、身体的魅力への選好の性差に影 響する可能性は低いと言えるだろう。加えて、日本は国別のジェンダー平等度評価(World Economic Forum, 2018)において下位（149 国中 110 位）に位置している。仮にジェンダ 究の結果はそれと逆のパターンを示していたことになる。何が性差を縮小させるのか、他 国、他時代のデータと合わせた探索的な分析によって検討する必要がある。

\section{その他の先行研究との違い}

最後に、直接に進化心理学的な予測のない項目に着目して、先行研究との違いを検討し ておきたい。それらは、離婚歴、子持ちであること、宗教の違い、人種の違いの 4 項目であ った。本研究の調査では、これらの特徵は全て男女ともに平均点が 7 段階評価で 4 点を下 回っていた。つまり一般的に結婚相手として望まれない特性であることが示された。そし て、人種の違いを除く 3 項目については、女性の方がより否定的な評価を与えていた。

これらの項目について、先行研究の結果は必ずしも一貫したものではなかった。唯一、 2つの先行研究で性差が一貫して観察されていたのが「すでに子持ちである」項目であり、 いずれも女性の方が相対的に好意な評価を与えていた。これは本論文の結果とは逆方向の性 40 差であった。また、Sprecher et al. (1994)では男性は否定的（平均 3.42 点）、女性はほぼ 41 中立的な評価（平均 4.07 点）を与えた上での性差であったが、Bech-Sørensen \& Pollet 
1 (2016)では男女とともに否定的評価を与えた上での性差であった（男性平均 2.84 点, 女性 2 平均 3.11 点）。

このように、相対的な性差ではなく、評価が中点より好意的または否定的であったのか という点からの検討も重要だろう。事実、本研究では男女の平均は一貫して否定的であった これらの特性だが、米国人回答者の評価は必ずしも否定的でなかった。より正確には 1994 年から 2016 年への 20 年間に価值観の転換が生じたことが伺われた。例えば離婚歴につい ては 1994 年時点の米国では男女ともに否定的な評価であったものが（男女とも平均 $<3.5$

点）、2016 年には中立または好意的な評価へと変わっている。人種が異なることについて

は、1994 年の米国では男女とも否定的であったが、2016 年には男女とも好意的評価に転 じている。また宗教が異なることについては、1994 年、2016 年を通じて米国の男女回答 者とも好意的に評価していた。結婚相手を選好する基準が地域や時代、もしくは文化によっ

て異なること、変化し得ることを如実に表していると言える。

本研究の結果、一方では進化心理学的知見の頑健さが確認された。すなわち年齢、経済 に大きいものであった。他方で、これまで頑健に観察されてきた、そして進化心理学的仮説 の柱の一つでもある身体的魅力にかんしては性差は再現されなかった。その理由を明らかに することは本研究のスコープを外れるものであり、将来の研究を待ちたい。また本研究の結 果だけをもって進化心理学的仮説が否定されるものではないことは言を俟たない。事実、数 多の先行研究の中で、本研究の結果は例外的とも言えるものである。本研究の意義は、当初 の目的にも述べたように、理論的に予測・予測されてきた知見であっても、その普遍性を確 認する作業が不断に求められることを示したことにあると言える。そしてデータの公開と共 有を通じて本研究が、人間行動と社会の変化をもたらす普遍的な人間性（Human universals; Brown, 1991)を明らかにする一助となることを期待する。

\section{引用文献一覧}

Andersson, M., \& Iwasa, Y. (1996). Sexual selection. Trends in Ecology and Evolution, 11(2), 53-58. https://doi.org/10.1016/j.cub.2010.11.053

Bech-Sørensen, J., \& Pollet, T. V. (2016). Sex Differences in Mate Preferences: a Replication Study, 20 Years Later. Evolutionary Psychological Science, 2(3), 171-176. https://doi.org/10.1007/s40806-016-0048-6

Boothroyd, L. G., Cross, C. P., Gray, A. W., Coombes, C., \& Gregson-Curtis, K. (2011). Perceiving the facial correlates of sociosexuality: Further evidence. Personality and Individual Differences, 50(3), 422-425. https://doi.org/10.1016/j.paid.2010.10.017

Boothroyd, L. G., Jones, B. C., Burt, D. M., DeBruine, L. M., \& Perrett, D. I. (2008). Facial correlates of sociosexuality. Evolution and Human Behavior, 29(3), $211-$ 218. https://doi.org/10.1016/j.evolhumbehav.2007.12.009

Boxer, C. F., Noonan, M. C., \& Whelan, C. B. (2013). Measuring Mate Preferences. Journal of Family Issues, 36(2), 163-187. https://doi.org/10.1177/0192513x13490404

Brown, D. E. (1991). Human universals. Temple University Press. 
Buss, D. M. (1989). Sex differences in human mate preferences: Evolutionary hypotheses tested in 37 cultures. Behavioral and Brain Sciences, 12(1989), 1-49. https://doi.org/10.1017/S0140525X00023992

Buss, D. M., Abbott, M., Angleitner, A., Asherian, A., Biaggio, A., Blanco-Villasenor, A., ‥ Yang, K. S. (1990). International preferences in selecting mates: A Study of 37 Cultures. Journal of Cross-Cultural Psychology, 21(1), 5-47. https://doi.org/10.1177/0022022190211001

Buss, D. M., \& Schmitt, D. P. (2019). Mate Preferences and Their Behavioral Manifestations. Annual Review of Psychology, 70(1), annurev-psych-010418103408. https://doi.org/10.1146/annurev-psych-010418-103408

Buss, D. M., Shackelford, T. K., Kirkpatrick, L. A., \& Larsen, R. J. (2001). A half century of mate preferences: The cultural evolution of values. Journal of Marriage and Family, 63(2), 491-503. https://doi.org/10.1111/j.17413737.2001.00491.x

Darwin, C. (1871). The descent of man and selection in relation to sex. London: John Murray.

Eagly, A. H., \& Wood, W. (1999). The Origins of Sex Differences in Human Behavior: Evolved Dispositions Versus Social Roles. American Psychologist, 54(6), 408423. https://doi.org/10.1037/0003-066X.54.6.408

Hill, R. (1945). Campus values in mate selection. Journal of Home Economics, 37, 554-558.

Hiraishi, K., Saito, A., Nishio, M., Fujii, N., \& Mori, T. (2019). Sex difference in mate preference based on physical attractiveness in Japan: No longer present or still present? PsyArXiv. https://doi.org/10.31234/OSF.IO/ACY9Z

Lakens, D. (2016). TOST equivalence testing R package (TOSTER) and spreadsheet. Retrieved April 28, 2019, from https://www.r-bloggers.com/tost-equivalencetesting-r-package-toster-and-spreadsheet/

Lakens, D. (2017). Equivalence Tests: A Practical Primer for t Tests, Correlations, and Meta-Analyses. Social Psychological and Personality Science, 8(4), 355-362. https://doi.org/10.1177/1948550617697177

Lakens, D., Scheel, A. M., \& Isager, P. M. (2018). Equivalence Testing for Psychological Research: A Tutorial. Advances in Methods and Practices in Psychological Science, 1(2), 259-269. https://doi.org/10.1 177/2515245918770963

Li, N. P., Kenrick, D. T., Bailey, J. M., \& Linsenmeier, J. A. W. (2002). The necessities and luxuries of mate preferences: Testing the tradeoffs. Journal of Personality and Social Psychology, 82(6), 947-955. https://doi.org/10.1037/0022-3514.82.6.947

Lovejoy, C. O. (1981). The origin of man. Science (New York, N.Y.), 21 1(4480), 341350. https://doi.org/21 1/4480/341 [pii]

Marlowe, F. (2000). Paternal investment and the human mating system. Behavioural Processes, 51(1-3), 45-61. https://doi.org/10.1016/S0376-6357(00)00118-2

三浦麻子 \& 小林哲郎. (2015). オンライン調査モニタのSatisficeに関する実験的研究. 社会 心理学研究, 31, 1-12. https://doi.org/10.14966/jssp.31.1_1

Penton-Voak, I. S., Perrett, D. I., Castles, D. L., Kobayashi, T., Burt, D. M., Murray, L. K., \& Minamisawa, R. (1999). Menstrual cycle alters face preference. Nature, 399(6738), 741-742. https://doi.org/10.1038/21557 
Sprecher, S., Sullivan, Q., \& Hatfield, E. (1994). Mate Selection Preferences: Gender Differences Examined in a National Sample. Journal of Personality and Social Psychology, 66(6), 1074-1080. https://doi.org/10.1037/0022-3514.66.6.1074 Trivers, R. L. L. (1972). Parental investment and sexual selection. In B. Campbell (Ed.), Sexual selection and the descent of man, 1871-1971 (pp. 136-179). Chicago: Aldine-Atherton. https://doi.org/10.1002/ajpa.1330400226

World Economic Forum. (2018). The Global Gender Gap Report 2018. Insight Report. Zhang, L., Lee, A. J., DeBruine, L. M., \& Jones, B. C. (2019). Are Sex Differences in Preferences for Physical Attractiveness and Good Earning Capacity in Potential Mates Smaller in Countries With Greater Gender Equality? Evolutionary Psychology, 17(2). https://doi.org/10.1177/1474704919852921

\section{Acknowledgement}

本研究の実施にあたって JSPS 科研費 15K13122, 19H01750 ならびに慶應義塾学事振興 基金（2018 年度個人研究）の助成を受けた。研究 2 の計画立案ならびに本論文の執筆に際 して「心理学評論」編集委員である三浦麻子氏、友永雅巳氏、二名の查読者より多くの建設 的かつ貴重な助言を得た。ここに記して感謝する。 
Table 1. Means and effects of sex on mate preference: Comparison with two preceding studies.

Listed below are considerations that are

important to some people in thinking about

WHETHER TO MARRY someone P各条件を有する人につい

結婚対象としての好ましさを回答し

circle how willing you would be to marry てください。

someone who..

日本語版

Sprencher et al. (1994)

Bech-Sørensen \& Pollet

Original Items

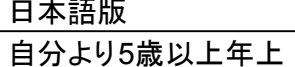
(2016)

Study 1 pre-test

Study 1 main survey

1. was older than you by 5 or more years,

2. was younger than you by 5 or more years 自分より5歳以上年下

3. had been married before

離婚歴がある

4. already had children

すでに子持ちである

5. was not likely to hold a steady job

6. was of a different religion

定職に就きそうにない

自分と宗教が異なる

7. was of a different race

8. would earn much less than you

9. would earn much more than you

10. was not "good-looking"

自分と人種が異なる

自分よりもはるかに収入が低い

自分よりもはるかに収入が高い

容姿がよくない

11. had more education than you

自分より学歴が高い

male female

male

female

$\frac{d}{0.58}$

$\begin{array}{cc}\text { male } & \text { female } \\ 3.62 & \mathbf{4 . 4 2}\end{array}$

$\begin{array}{lll}4.54 & 2.80 & 1.09\end{array}$

5.03

0.65

$g$

$-0.53$

male female

$\frac{g}{-0.52}$

$\begin{array}{lll}3.35 & 3.44 & 0.08\end{array}$

$2.84 \quad 3.11-0.17$

$\begin{array}{lll}4.05 & 4.37 & 0.22\end{array}$

$3.02 \quad 2.76$

0.79

$3.68 \quad 4.43$

$\begin{array}{lll}4.44 & 3.35 & 0.76\end{array}$

$\begin{array}{llll}2.84 & 3.11 & 0.17 & 3.42\end{array}$

$4.07 \quad 0.40$

$2.63 \quad 2.31$

0.19

0.22

$4.24-4.31-0.05$

$\begin{array}{lll}3.26 & 2.42 & 0.57\end{array}$

$\begin{array}{lll}4.38 & 4.21 & 0.11\end{array}$

$2.91 \quad 1.73$

$3.42 \quad 2.79$

0.88

$3.11 \quad 2.82$

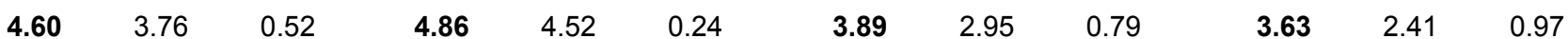

$\begin{array}{lll}2.95 & 0.79-3.63-2.41-0.97\end{array}$

$\begin{array}{llllllllllll}5.19 & \mathbf{5 . 9 3} & 0.55 & 5.22 & \mathbf{5 . 7 6} & 0.40 & 4.24 & \mathbf{5 . 4 2} & -0.89 & 4.18 & \mathbf{4 . 9 1} & -0.50\end{array}$

12. had less education than you

全く結婚したくない, 結婚したくない,

$\begin{array}{ll}\text { Each of these items was followed by a } 7- & \text { 全く結婚したくない, 結婚したくない } \\ \text { point }(1=\text { not at all and } 7 \text { =very willing) } & \text { どちらかという結し婚しくない, }\end{array}$

Likert response scale.

どちらでもない, どちらかというと結

婚したい, 結婚したい, 非常に結婚

したい

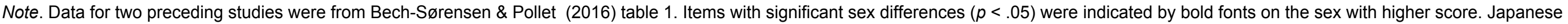
version of item 10 was "容姿がよくはない " for pre-test and "容姿がよくない " for main survey. 
Table 2. Detailed resutls for study 1 pre-test and main survey.

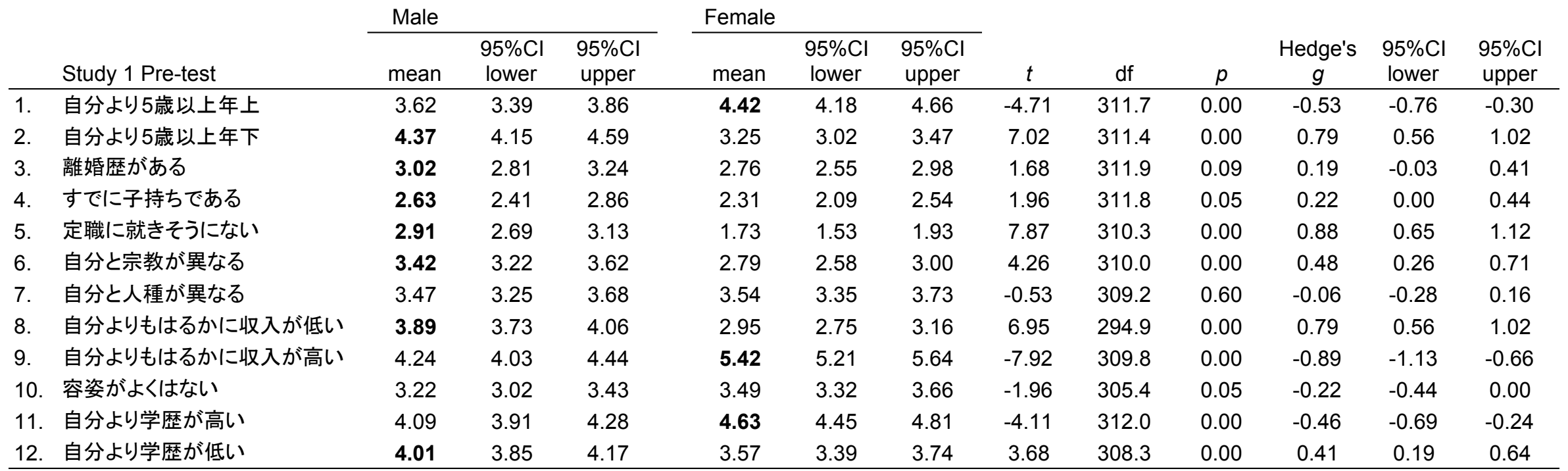

\begin{tabular}{|c|c|c|c|c|c|c|c|c|c|c|c|c|c|}
\hline & \multirow[b]{2}{*}{ Study 1 Main survey } & \multicolumn{3}{|l|}{ male } & \multicolumn{3}{|c|}{ Female } & \multirow[b]{2}{*}{$t$} & \multirow[b]{2}{*}{ df } & \multirow[b]{2}{*}{$p$} & \multirow[b]{2}{*}{$\begin{array}{c}\text { Hedge's } \\
g\end{array}$} & \multirow[b]{2}{*}{$\begin{array}{l}95 \% \mathrm{Cl} \\
\text { lower }\end{array}$} & \multirow[b]{2}{*}{$\begin{array}{l}95 \% \mathrm{Cl} \\
\text { upper }\end{array}$} \\
\hline & & mean & $\begin{array}{l}95 \% \mathrm{Cl} \\
\text { lower }\end{array}$ & $\begin{array}{l}95 \% \mathrm{Cl} \\
\text { upper }\end{array}$ & mean & $\begin{array}{l}95 \% \mathrm{Cl} \\
\text { lower }\end{array}$ & $\begin{array}{l}95 \% \mathrm{Cl} \\
\text { upper }\end{array}$ & & & & & & \\
\hline 1. & 自分より5歳以上年上 & 3.68 & 3.50 & 3.86 & 4.43 & 4.25 & 4.62 & -5.76 & 480.8 & 0.00 & -0.52 & -0.70 & -0.34 \\
\hline 2. & 自分より5歳以上年下 & 4.44 & 4.26 & 4.62 & 3.35 & 3.16 & 3.53 & 8.36 & 479.4 & 0.00 & 0.76 & 0.57 & 0.94 \\
\hline 3. & 離婚歴がある & 3.11 & 2.94 & 3.29 & 2.82 & 2.67 & 2.97 & 2.48 & 481.5 & 0.01 & 0.22 & 0.04 & 0.40 \\
\hline 4. & すでに子持ちである & 2.84 & 2.66 & 3.03 & 2.33 & 2.17 & 2.49 & 4.19 & 480.4 & 0.00 & 0.38 & 0.20 & 0.56 \\
\hline 5. & 定職に就きそうにない & 3.20 & 3.03 & 3.37 & 1.59 & 1.45 & 1.72 & 14.52 & 467.6 & 0.00 & 1.29 & 1.10 & 1.49 \\
\hline 6. & 自分と宗教が異なる & 3.32 & 3.14 & 3.49 & 2.87 & 2.69 & 3.04 & 3.55 & 482.1 & 0.00 & 0.32 & 0.14 & 0.50 \\
\hline 7. & 自分と人種が異なる & 3.42 & 3.25 & 3.58 & 3.39 & 3.23 & 3.56 & 0.20 & 483.4 & 0.85 & 0.02 & -0.16 & 0.20 \\
\hline 8. & 自分よりもはるかに収入が低い & 3.63 & 3.47 & 3.78 & 2.41 & 2.24 & 2.57 & 10.64 & 473.2 & 0.00 & 0.97 & 0.78 & 1.16 \\
\hline 9. & 自分よりもはるかに収入が高い & 4.18 & 4.00 & 4.35 & 4.91 & 4.71 & 5.11 & -5.49 & 462.5 & 0.00 & -0.50 & -0.68 & -0.32 \\
\hline 10. & 容姿がよくない & 3.32 & 3.16 & 3.49 & 3.45 & 3.30 & 3.59 & -1.10 & 477.7 & 0.27 & -0.10 & -0.28 & 0.08 \\
\hline 11. & 自分より学歴が高い & 4.12 & 3.97 & 4.27 & 4.62 & 4.44 & 4.79 & -4.26 & 469.3 & 0.00 & -0.39 & -0.57 & -0.21 \\
\hline 12. & 自分より学歴が低い & 3.97 & 3.84 & 4.10 & 3.60 & 3.45 & 3.75 & 3.70 & 467.7 & 0.00 & 0.34 & 0.16 & 0.52 \\
\hline
\end{tabular}

Note. Where sex differences were significant $(p<.05)$, sex with higher mean score was indicated by bold fonts. 
身体的魅力の重視度における男女差は消えたのか

Table 3. Correlations among age and score on each item in study 1

\begin{tabular}{|c|c|c|c|c|c|c|c|c|c|c|c|c|c|c|c|c|c|}
\hline & \multirow[b]{3}{*}{ Items } & \multicolumn{8}{|c|}{ Study 1 Pretest } & \multicolumn{8}{|c|}{ Study 1 Main Survey } \\
\hline & & \multirow{2}{*}{$\frac{\text { Male }}{\mathrm{n}}$} & \multicolumn{3}{|c|}{$95 \% \mathrm{Cls}$} & \multirow{2}{*}{$\frac{\text { Female }}{n}$} & \multicolumn{3}{|c|}{$95 \% \mathrm{Cls}$} & \multirow{2}{*}{$\frac{\text { Male }}{\mathrm{n}}$} & \multicolumn{3}{|c|}{$95 \% \mathrm{Cls}$} & \multirow{2}{*}{$\frac{\text { Female }}{n}$} & \multicolumn{3}{|c|}{$95 \% \mathrm{Cls}$} \\
\hline & & & $r$ & lower & upper & & $r$ & lower & upper & & $r$ & lower & upper & & $r$ & lower & upper \\
\hline 1. & 自分より5歳以上年上 & 161 & -0.07 & -0.22 & 0.09 & 153 & -0.12 & -0.28 & 0.04 & 257 & -0.10 & -0.22 & 0.02 & 229 & 0.07 & -0.06 & 0.20 \\
\hline 2. & 自分より5歳以上年下 & 161 & 0.13 & -0.02 & 0.28 & 153 & 0.13 & -0.03 & 0.28 & 257 & 0.16 & 0.04 & 0.28 & 229 & 0.12 & -0.01 & 0.24 \\
\hline 3. & 離婚歴がある & 161 & 0.06 & -0.09 & 0.22 & 153 & 0.11 & -0.05 & 0.27 & 257 & 0.02 & -0.11 & 0.14 & 229 & 0.09 & -0.04 & 0.21 \\
\hline 4. & すでに子持ちである & 161 & 0.06 & -0.10 & 0.21 & 153 & -0.05 & -0.20 & 0.11 & 257 & -0.02 & -0.14 & 0.11 & 229 & 0.04 & -0.09 & 0.17 \\
\hline 5. & 定職に就きそうにない & 161 & 0.06 & -0.10 & 0.21 & 153 & -0.14 & -0.29 & 0.02 & 257 & 0.01 & -0.11 & 0.13 & 229 & -0.04 & -0.16 & 0.09 \\
\hline 6. & 自分と宗教が異なる & 161 & 0.10 & -0.05 & 0.25 & 153 & -0.03 & -0.19 & 0.13 & 257 & -0.04 & -0.17 & 0.08 & 229 & -0.05 & -0.18 & 0.08 \\
\hline 7. & 自分と人種が異なる & 161 & 0.02 & -0.14 & 0.17 & 153 & -0.02 & -0.18 & 0.14 & 257 & 0.03 & -0.10 & 0.15 & 229 & -0.07 & -0.20 & 0.06 \\
\hline 8. & 自分よりもはるかに収入が低い & 161 & 0.03 & -0.13 & 0.18 & 153 & -0.04 & -0.20 & 0.12 & 257 & 0.01 & -0.12 & 0.13 & 229 & 0.00 & -0.13 & 0.13 \\
\hline 9. & 自分よりもはるかに収入が高い & 161 & -0.05 & -0.20 & 0.11 & 153 & -0.16 & -0.31 & 0.00 & 257 & -0.05 & -0.17 & 0.08 & 229 & -0.12 & -0.25 & 0.01 \\
\hline 10. & 容姿がよくない & 161 & 0.01 & -0.14 & 0.17 & 153 & 0.02 & -0.14 & 0.17 & 257 & -0.04 & -0.16 & 0.08 & 229 & 0.00 & -0.13 & 0.13 \\
\hline 11. & 自分より学歴が高い & 161 & -0.08 & -0.23 & 0.07 & 153 & -0.17 & -0.32 & -0.01 & 257 & -0.07 & -0.20 & 0.05 & 229 & -0.18 & -0.30 & -0.05 \\
\hline \multirow[t]{2}{*}{12.} & 自分より学歴が低い & 161 & 0.04 & -0.12 & 0.19 & 153 & 0.02 & -0.14 & 0.18 & 257 & 0.04 & -0.09 & 0.16 & 229 & -0.03 & -0.15 & 0.10 \\
\hline & 選好度合計 & 161 & -0.20 & -0.35 & -0.05 & 153 & -0.10 & -0.25 & 0.06 & 257 & -0.10 & -0.22 & 0.03 & 229 & 0.03 & -0.10 & 0.16 \\
\hline
\end{tabular}

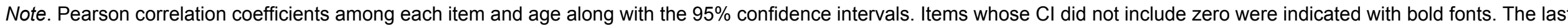
raw indicates "sum of preferences" which is a sum of deviations from the midpoint (4) on each item. 
Table 4. Mate preference means and effects of sex in study 2.

\begin{tabular}{|c|c|c|c|c|c|c|c|c|c|c|}
\hline & & \multicolumn{3}{|l|}{ Male } & \multicolumn{3}{|c|}{ Female } & \multirow[b]{2}{*}{$\begin{array}{c}\text { Hedge's } \\
g\end{array}$} & \multirow[b]{2}{*}{$\begin{array}{l}95 \% \mathrm{Cl} \\
\text { lower }\end{array}$} & \multirow[b]{2}{*}{$\begin{array}{l}95 \% \mathrm{Cl} \\
\text { upper }\end{array}$} \\
\hline & Study 2 & mean & $\begin{array}{l}95 \% \mathrm{Cl} \\
\text { lower }\end{array}$ & $\begin{array}{l}95 \% \mathrm{Cl} \\
\text { upper }\end{array}$ & mean & $\begin{array}{l}95 \% \mathrm{Cl} \\
\text { lower }\end{array}$ & $\begin{array}{l}95 \% \mathrm{Cl} \\
\text { upper }\end{array}$ & & & \\
\hline & 自分より5歳以上年上 & 4.02 & 3.83 & 4.20 & 4.43 & 4.26 & 4.60 & -0.29 & -0.47 & -0.12 \\
\hline 2. & 自分より5歳以上年下 & 4.59 & 4.41 & 4.76 & 3.56 & 3.37 & 3.74 & 0.71 & 0.53 & 0.89 \\
\hline 3. & 離婚歴がある & 3.39 & 3.21 & 3.56 & 2.92 & 2.75 & 3.08 & 0.35 & 0.17 & 0.53 \\
\hline 4. & すでに子持ちである & 3.05 & 2.85 & 3.24 & 2.36 & 2.20 & 2.52 & 0.48 & 0.30 & 0.66 \\
\hline 5. & 定職に就きそうにない & 3.15 & 2.96 & 3.34 & 1.73 & 1.58 & 1.89 & 1.02 & 0.84 & 1.21 \\
\hline 6. & 自分と宗教が異なる & 3.49 & 3.31 & 3.67 & 2.75 & 2.58 & 2.92 & 0.52 & 0.34 & 0.70 \\
\hline 7. & 自分と人種が異なる & 3.66 & 3.48 & 3.83 & 3.47 & 3.30 & 3.63 & 0.14 & -0.03 & 0.32 \\
\hline & 自分よりもはるかに収入が低い & 3.75 & 3.60 & 3.91 & 2.52 & 2.35 & 2.69 & 0.95 & 0.76 & 1.13 \\
\hline & 自分よりもはるかに収入が高い & 4.42 & 4.25 & 4.59 & 5.14 & 4.97 & 5.31 & -0.53 & -0.71 & -0.35 \\
\hline & 容姿が良い & 5.29 & 5.11 & 5.46 & 5.20 & 5.04 & 5.37 & 0.06 & -0.12 & 0.24 \\
\hline & 自分より学歴が高い & 4.37 & 4.21 & 4.52 & 4.76 & 4.61 & 4.92 & -0.32 & -0.50 & -0.14 \\
\hline 12 & 自分より学歴が低い & 4.02 & 3.89 & 4.16 & 3.57 & 3.42 & 3.71 & 0.40 & 0.23 & 0.58 \\
\hline
\end{tabular}

Note. Items whose $95 \% \mathrm{Cl}$ of the effects did not include zero were indicated by bold fonts (sex with higher score was idicated). 
Table 5. Correlations among age and score on each item in study 2.

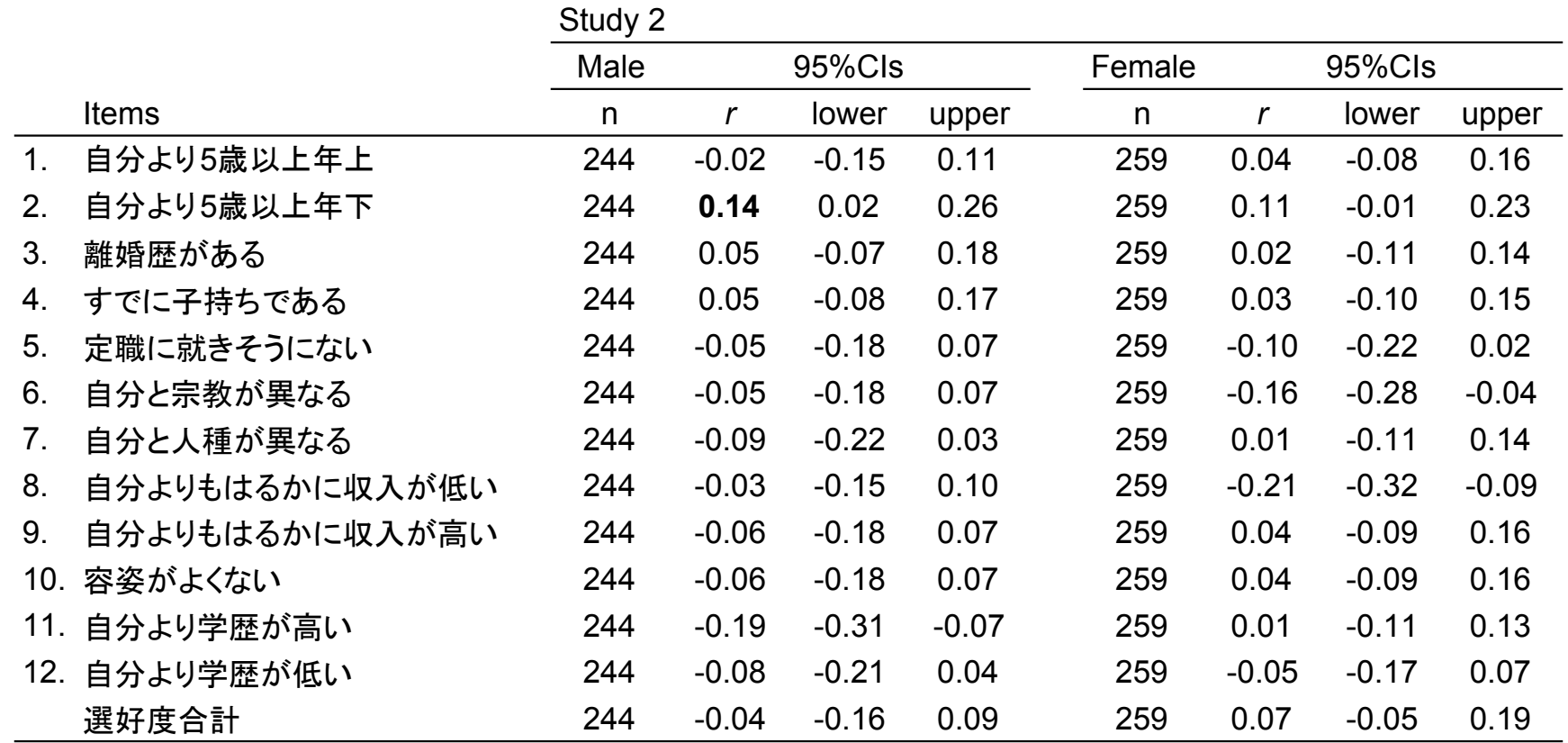

Note. Pearson correlation coefficients among each item and age along with the 95\% confidence intervals. Items whose $\mathrm{Cl}$ did not include zero were indicated with bold fonts. The last raw indicates "sum of preferences" which is a sum of deviations from the midpoint (4) on each item. 


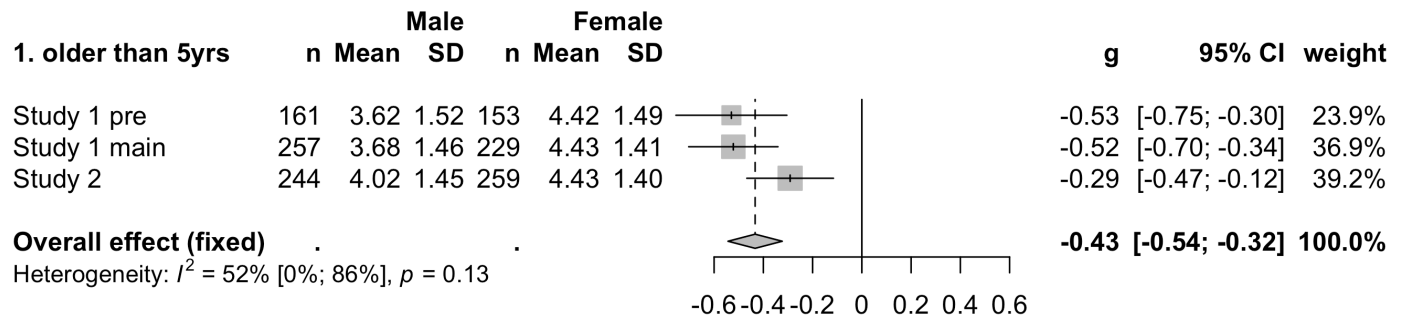

Male Female

2. younger than 5yrs n Mean SD n Mean SD

g $95 \% \mathrm{Cl}$ weight

$\begin{array}{lllllll}\text { Study } 1 \text { pre } & 161 & 4.37 & 1.42 & 153 & 3.25 & 1.41\end{array}$

Study 1 main $\quad 257 \quad 4.44 \quad 1.45229 \quad 3.351 .42$

$\begin{array}{lllllll}\text { Study } 2 & 244 & 4.59 & 1.39 & 259 & 3.56 & 1.50\end{array}$

Overall effect (fixed)

Heterogeneity: $I^{2}=0 \%[0 \% ; 35 \%], p=0.85$
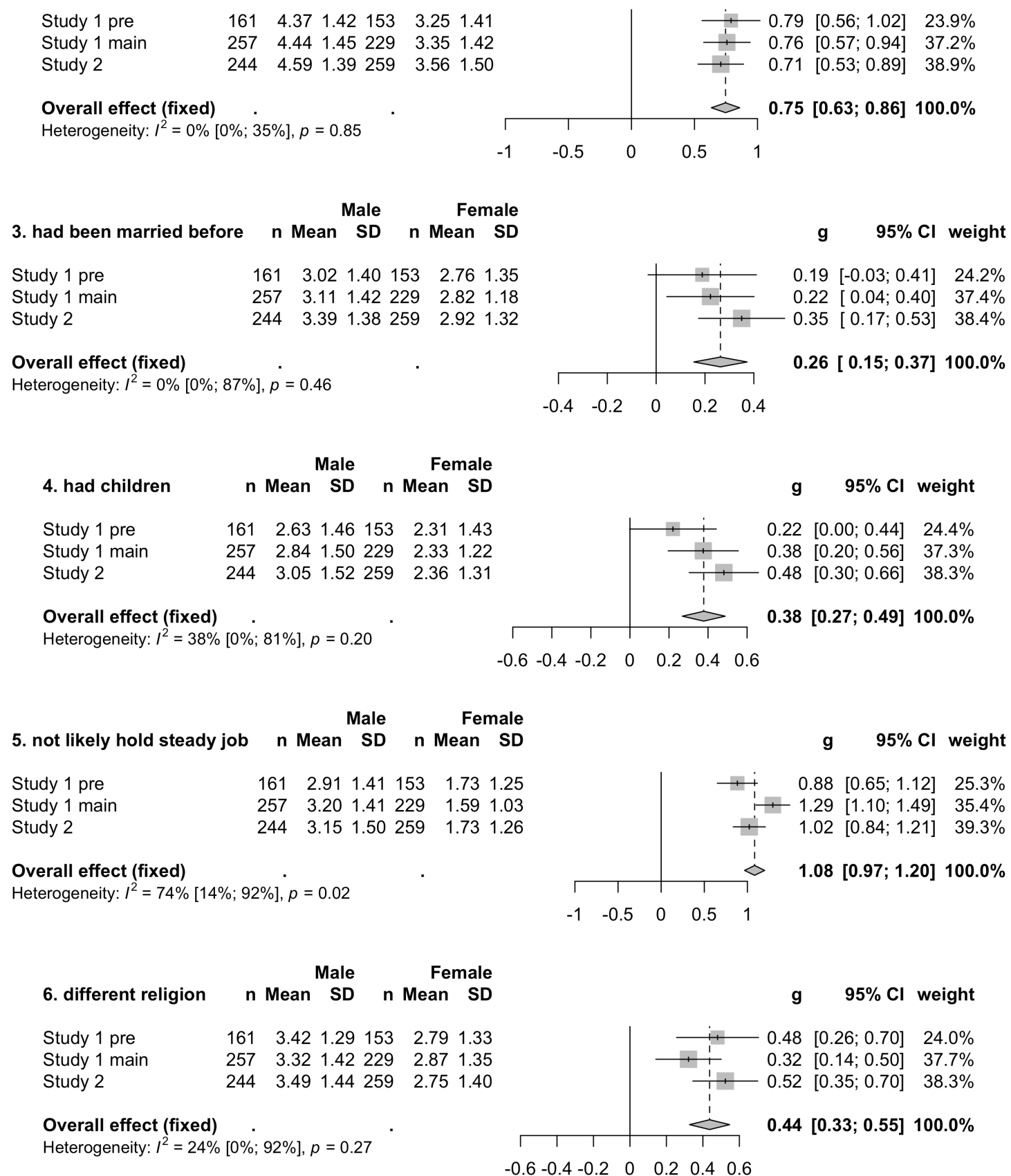

Figure 1A. Results of meta-analyses: item 1 to 5. 


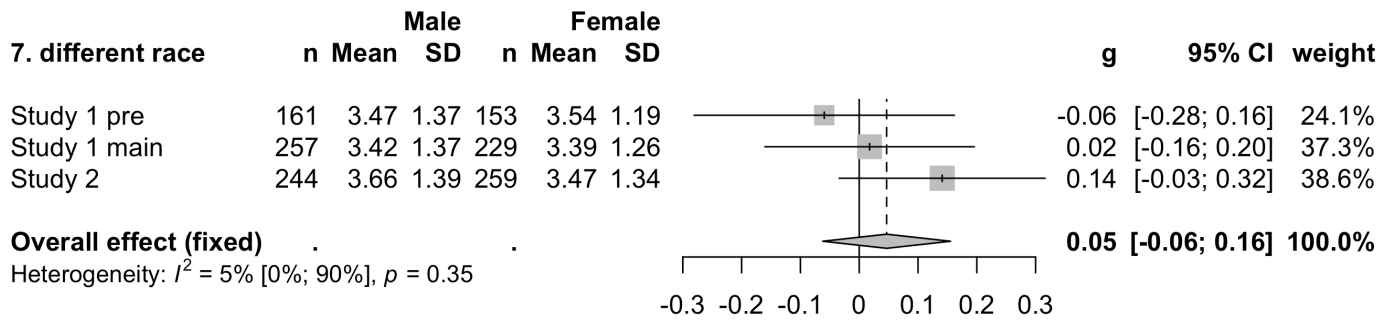

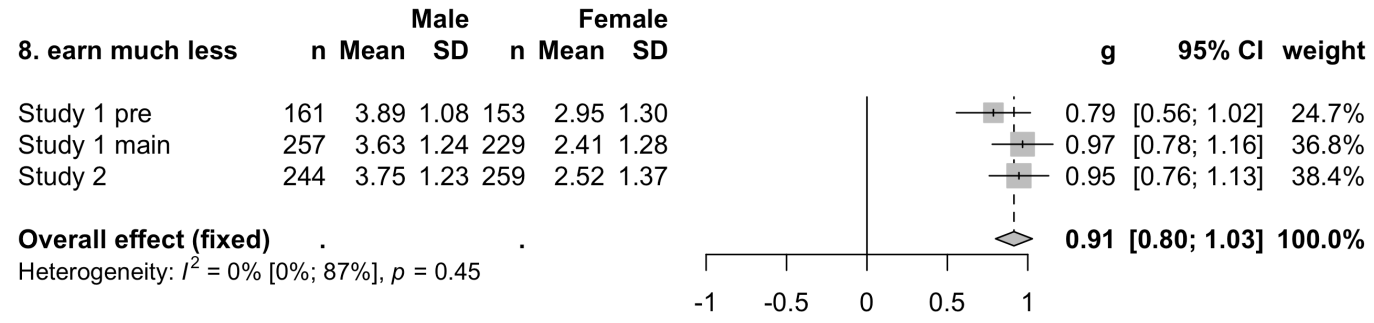

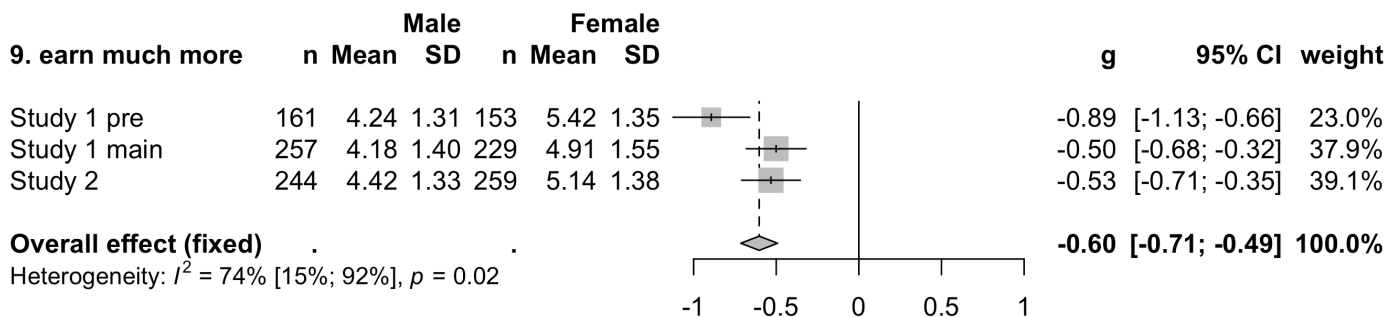

10. not good-looking $n$ Mean $\begin{array}{r}\text { Female } \\ \text { SD }\end{array}$

10. not good-looking $n$ Mean SD $n$ Mean SD

Study 1 pre

Study 1 main

$\begin{array}{llllll}161 & 3.22 & 1.32 & 153 & 3.49 & 1.08\end{array}$

$\begin{array}{lllllll}257 & 3.32 & 1.36 & 229 & 3.45 & 1.08\end{array}$

$\begin{array}{lllllll}\text { Study } 2 & 244 & 2.71 & 1.41 & 259 & 2.80 & 1.32\end{array}$

Overall effect (fixed)

Heterogeneity: $I^{2}=0 \%[0 \% ; 83 \%], p=0.53$

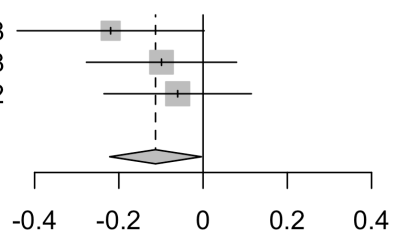

g $\quad 95 \% \mathrm{Cl}$ weight

$-0.22[-0.44 ; 0.00] \quad 24.0 \%$

$-0.10[-0.28 ; 0.08] \quad 37.3 \%$

$-0.06[-0.24 ; 0.11] \quad 38.7 \%$

$-0.11[-0.22 ; 0.00] 100.0 \%$

11. more education $\quad \begin{gathered}\text { Male } \\ \text { Female }\end{gathered}$

Study 1 pre $\quad 161 \quad 4.091 .18 \quad 153 \quad 4.63 \quad 1.12$

Study 1 main $\quad \begin{array}{lllllll}257 & 4.12 & 1.24 & 229 & 4.62 & 1.31\end{array}$

$\begin{array}{lllllll}\text { Study } 2 & 244 & 4.37 & 1.23 & 259 & 4.76 & 1.25\end{array}$

Overall effect (fixed)

Heterogeneity: $I^{2}=0 \%[0 \% ; 79 \%], p=0.61$

$\%$




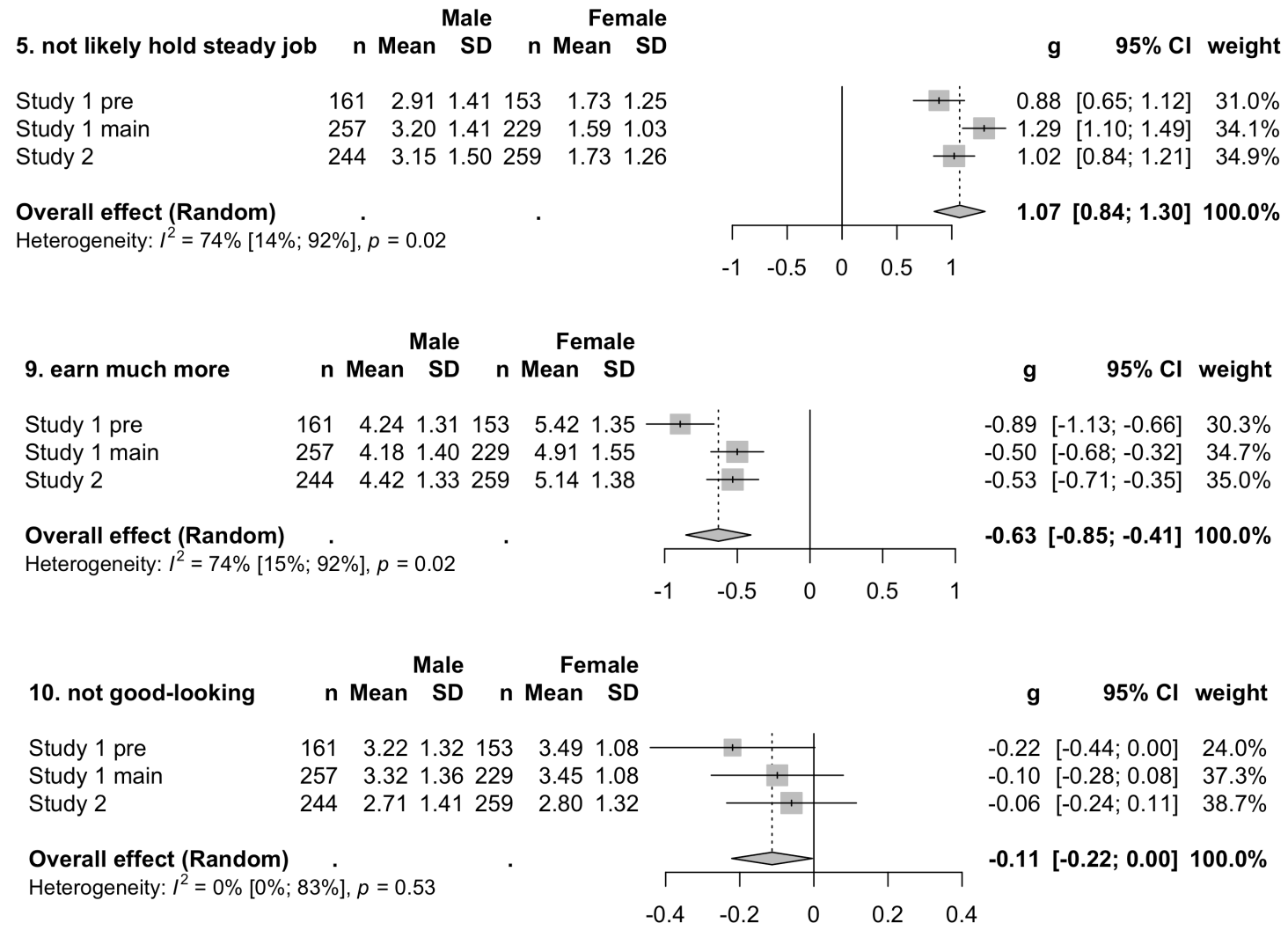

Figure 1C. Results of meta-analyses with random effect model for item 5, 9, and 10 . 
Supplementary Information

Kendall correlation coefficients (tau) among items are shown. Alphas were adjusted with the Bonferroni method. * $p<.05 / 78,{ }^{* *} p<.01 / 78,{ }^{* * *} p<.001 / 78$. 


\section{Study 1 (pre), All}

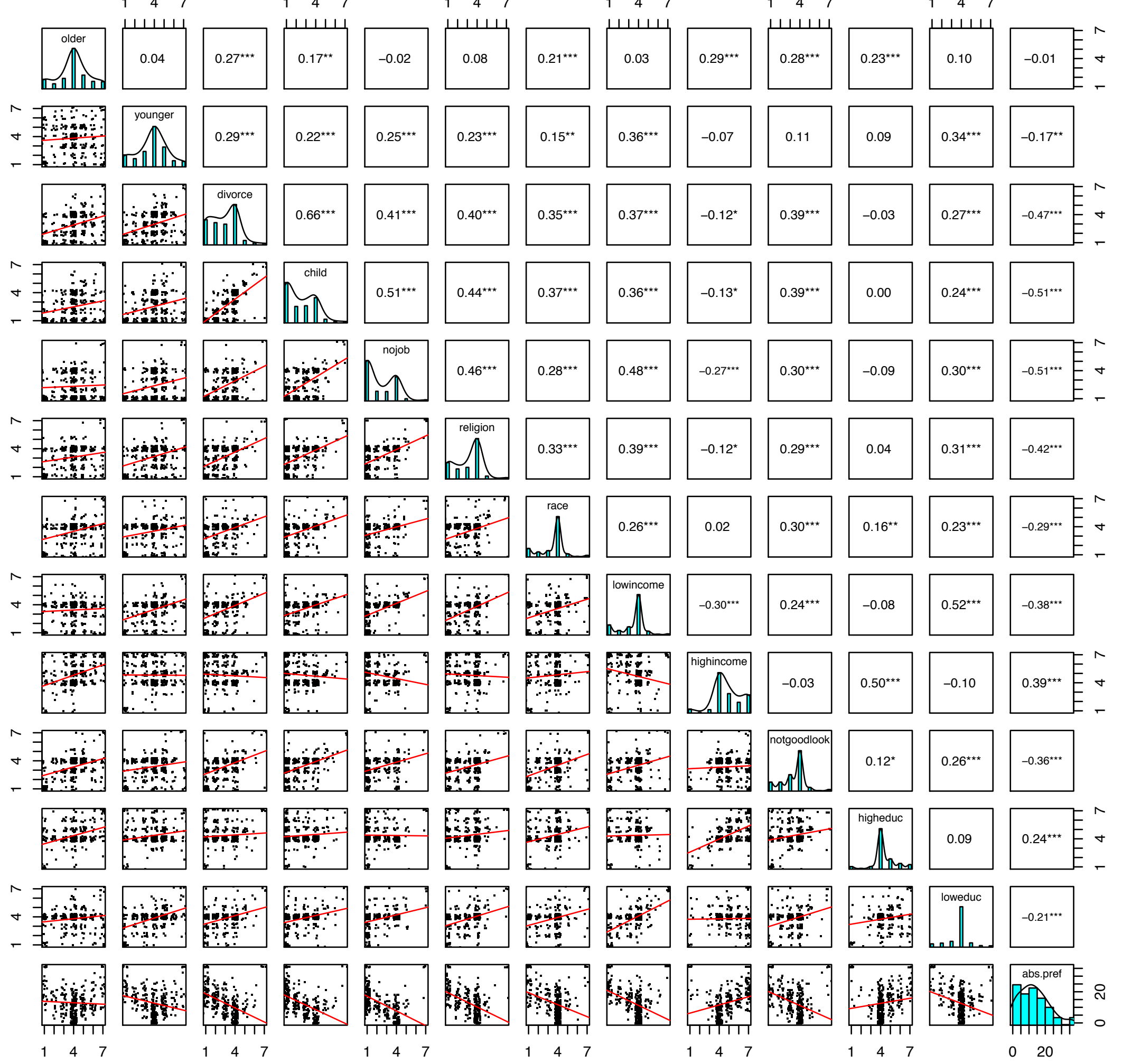




\section{Study 1 (pre), Male}

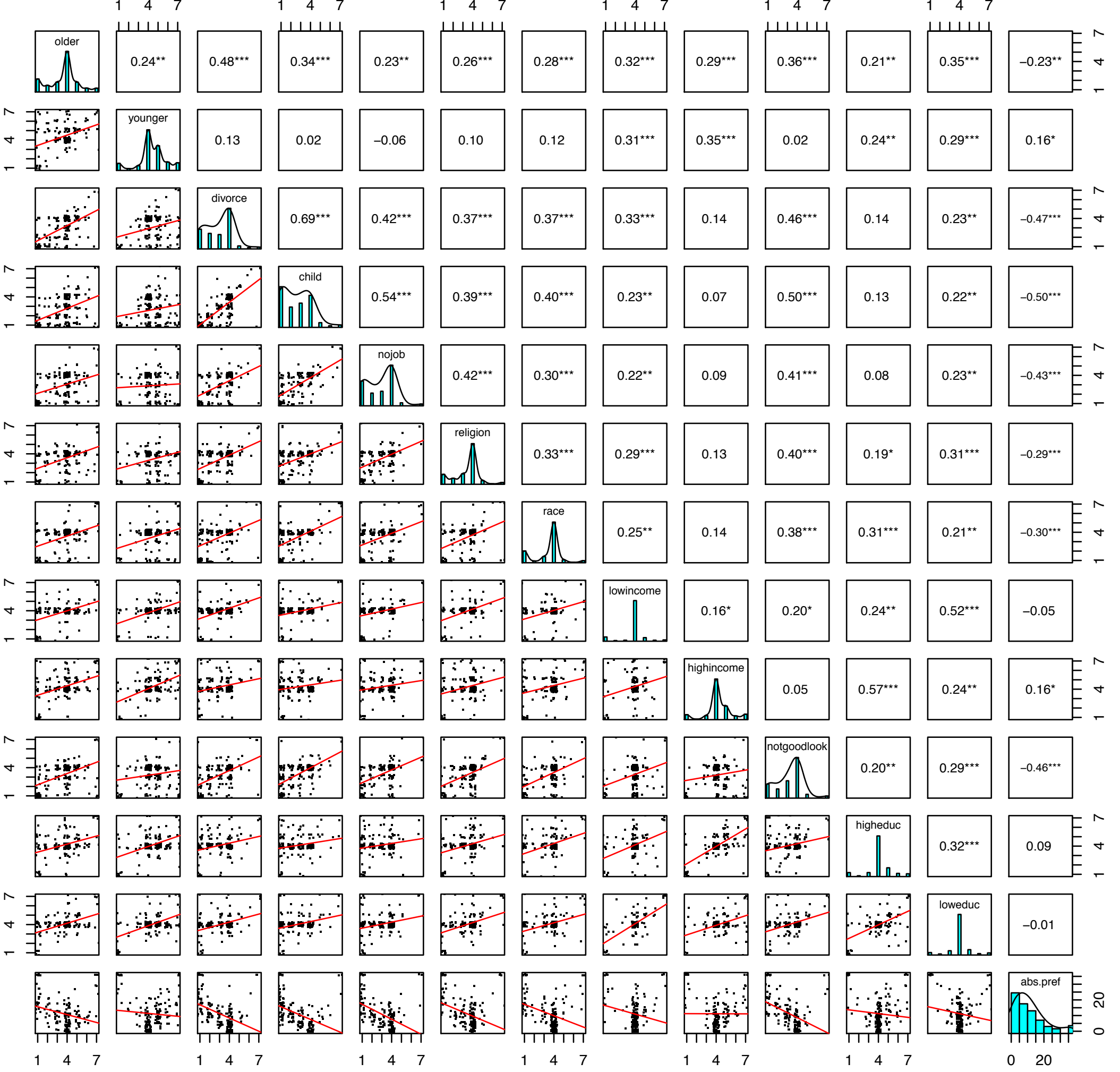




\section{Study 1 (pre), Female}

$\begin{array}{lll}1 & 4 & 7\end{array}$

older

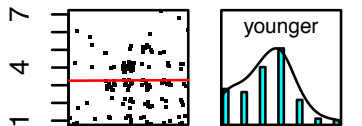

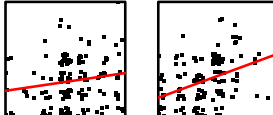

$+\exists$

-

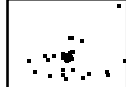

ast

ナ

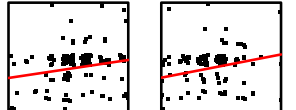

$\wedge$

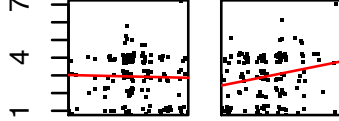

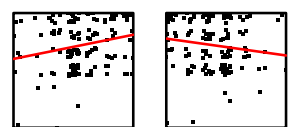

$\wedge$

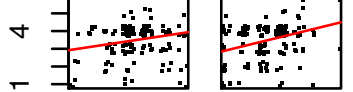

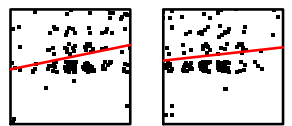

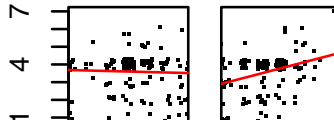

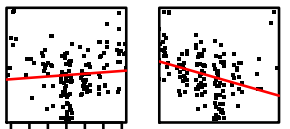

$\begin{array}{lll}1 & 4 & 7\end{array}$
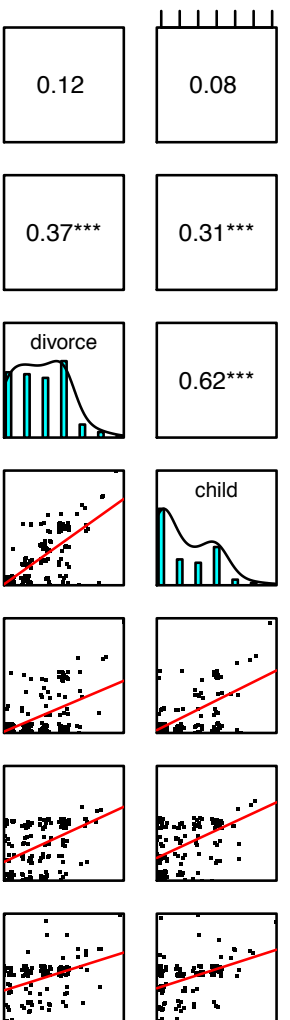

in.
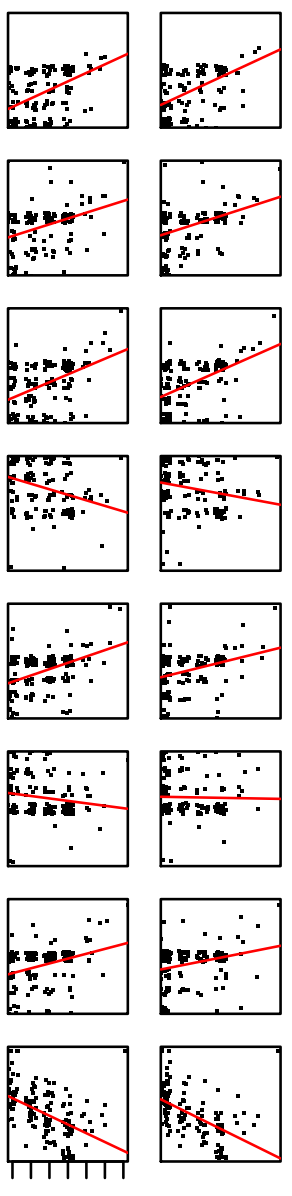
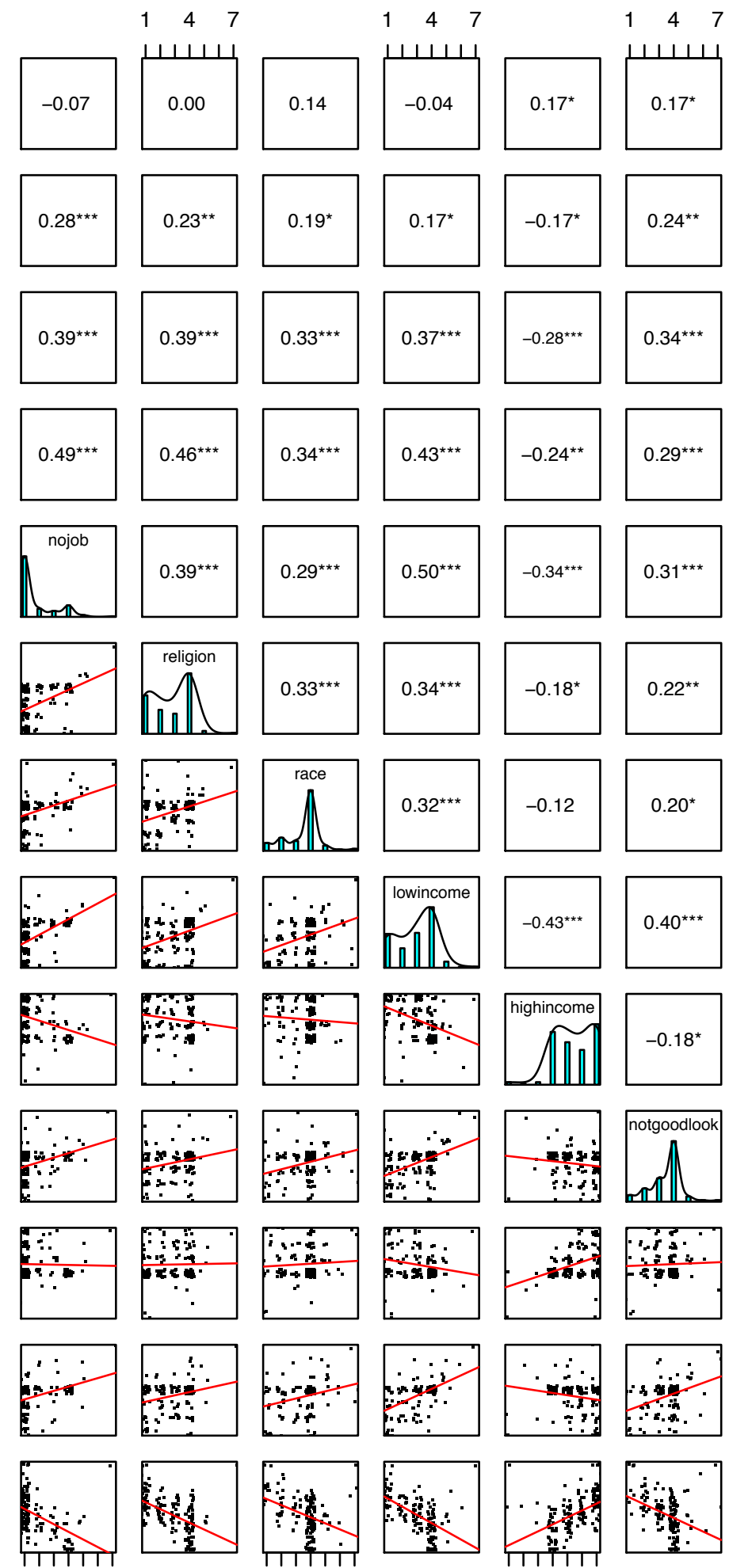

147
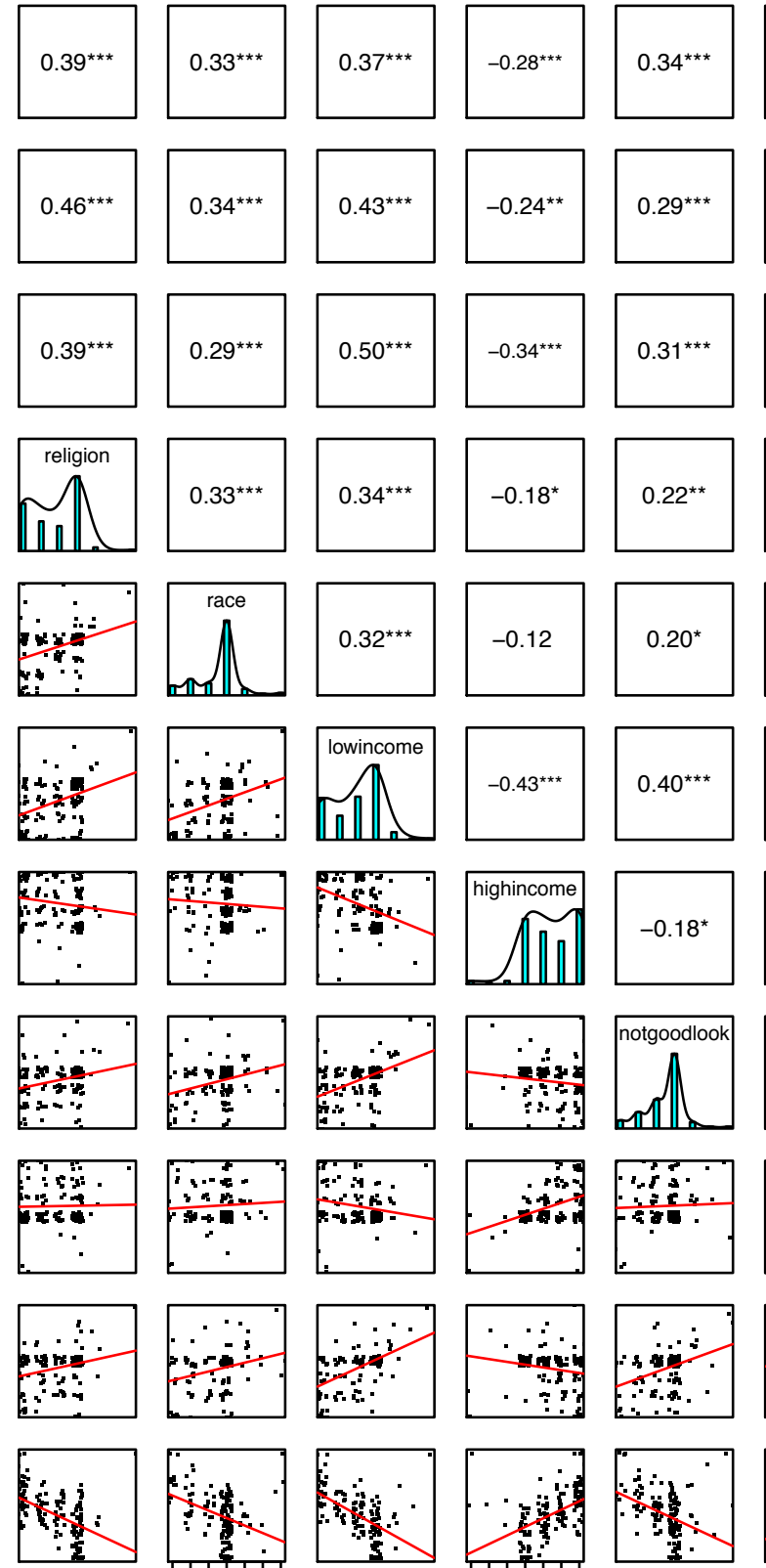

$\begin{array}{lll}1 & 4 & 7\end{array}$

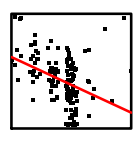

$\begin{array}{lll}1 & 4 & 7\end{array}$
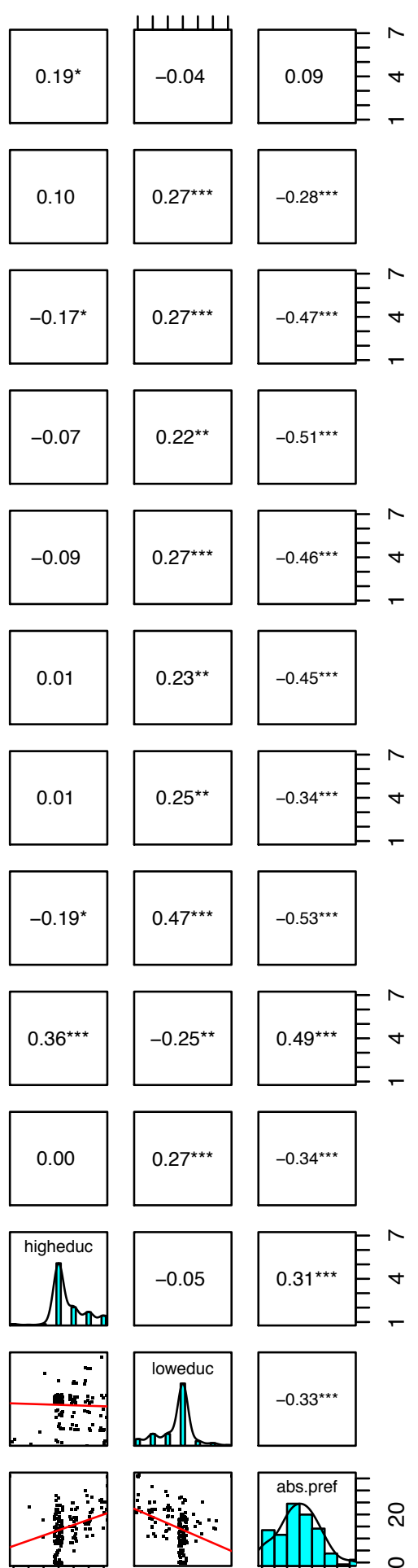

47
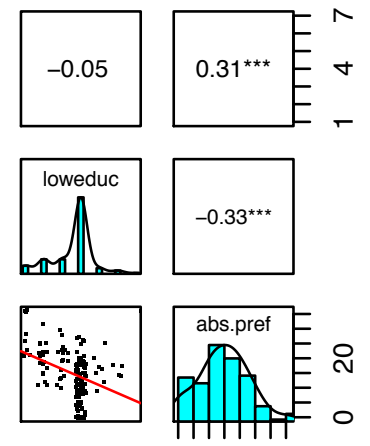

020 
Study 1 (main), All

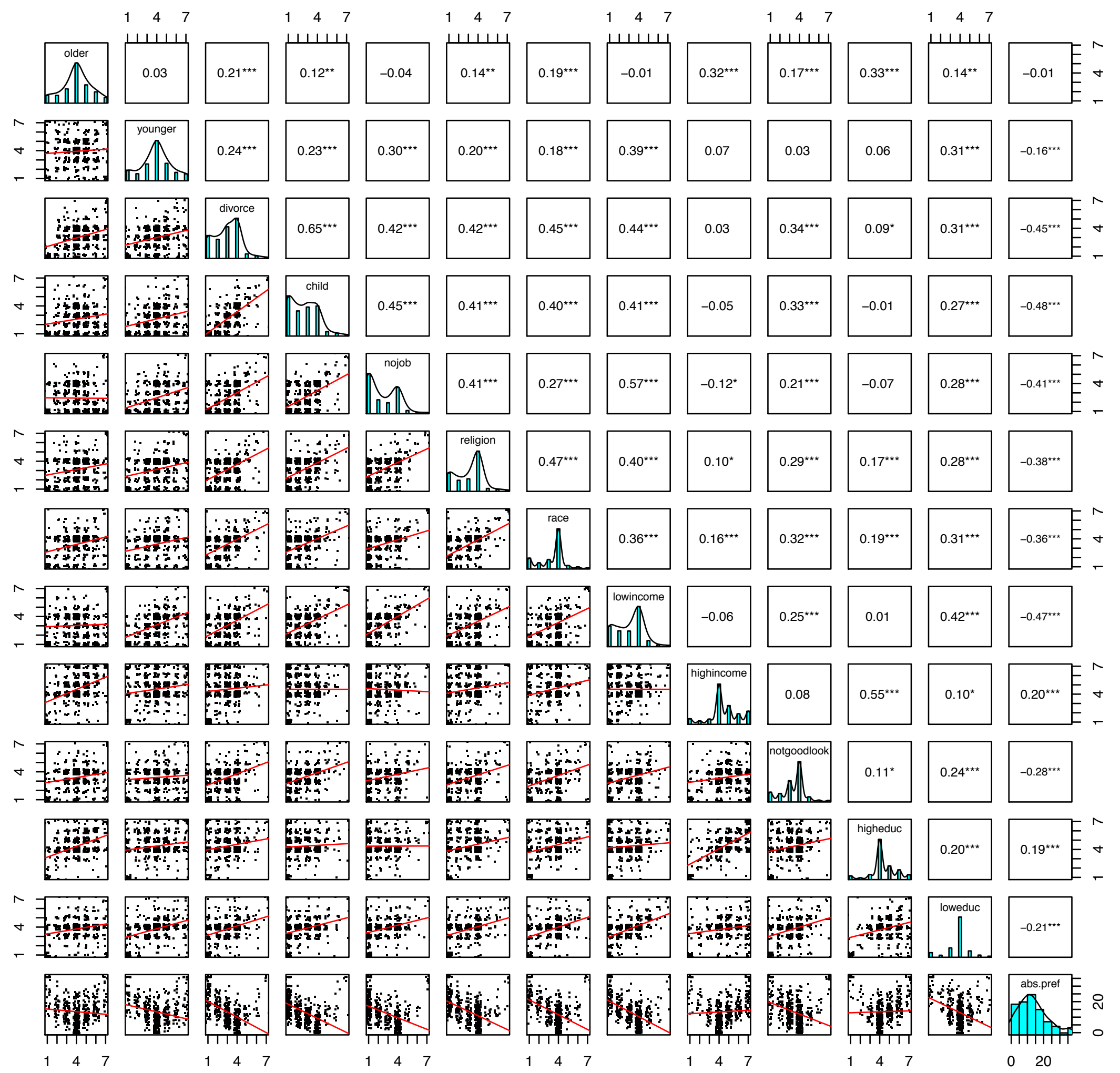


Study 1 (main), Male

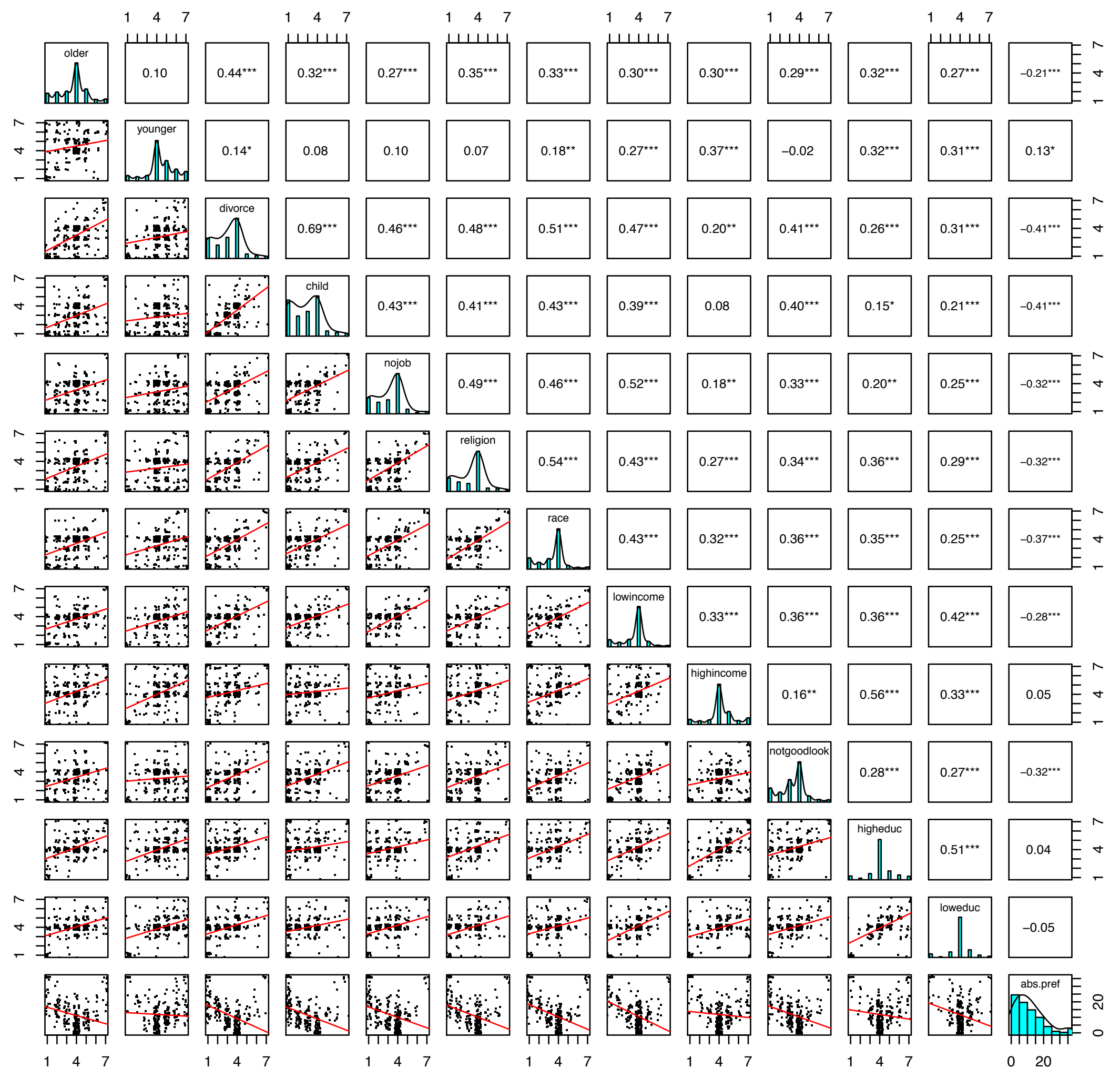




\section{Study 1 (main), Female}

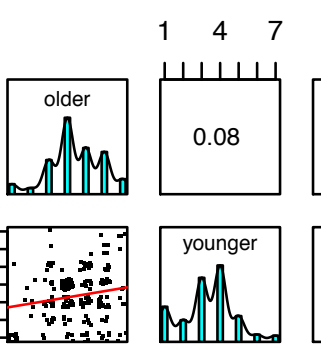

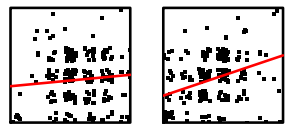

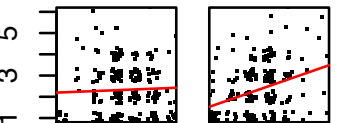

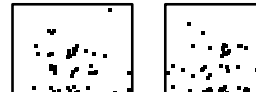

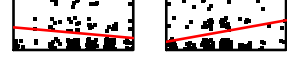

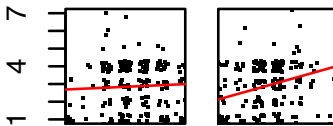

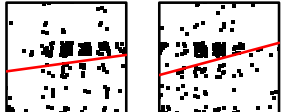

$\wedge=$

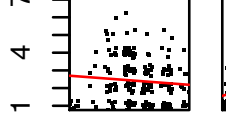

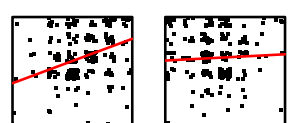

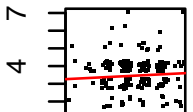

- = $\therefore: 3: 2$

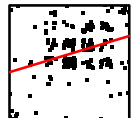
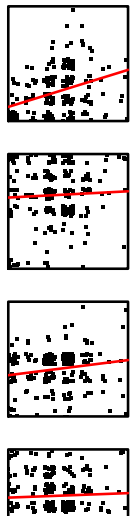

$\because \because$

包:

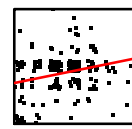

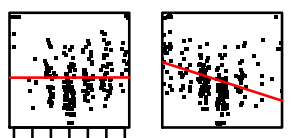

135
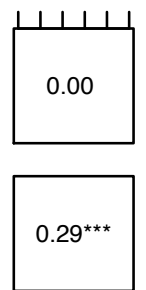

divere
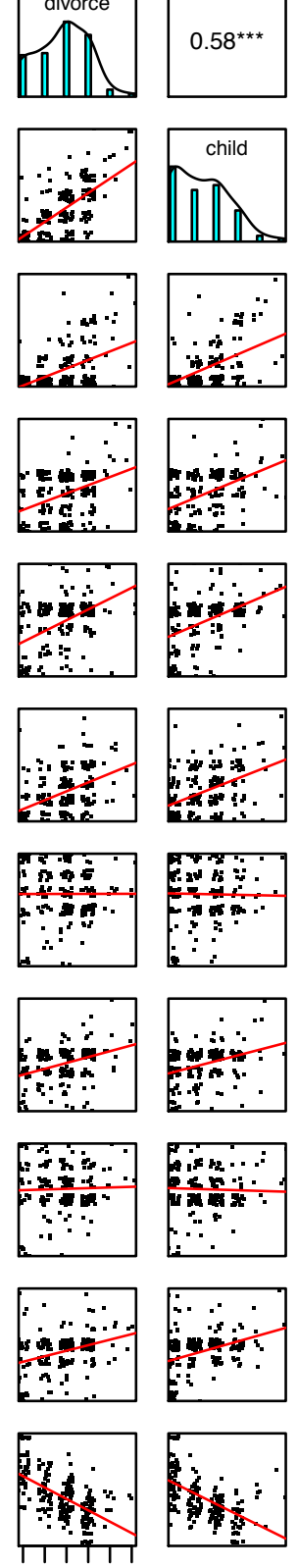

$\begin{array}{lll}14 & 4\end{array}$
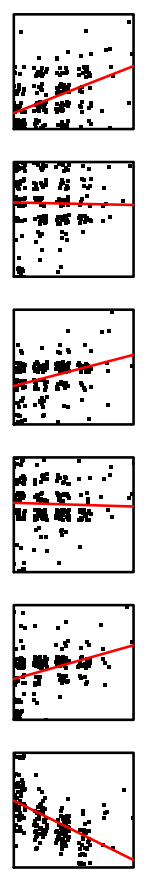
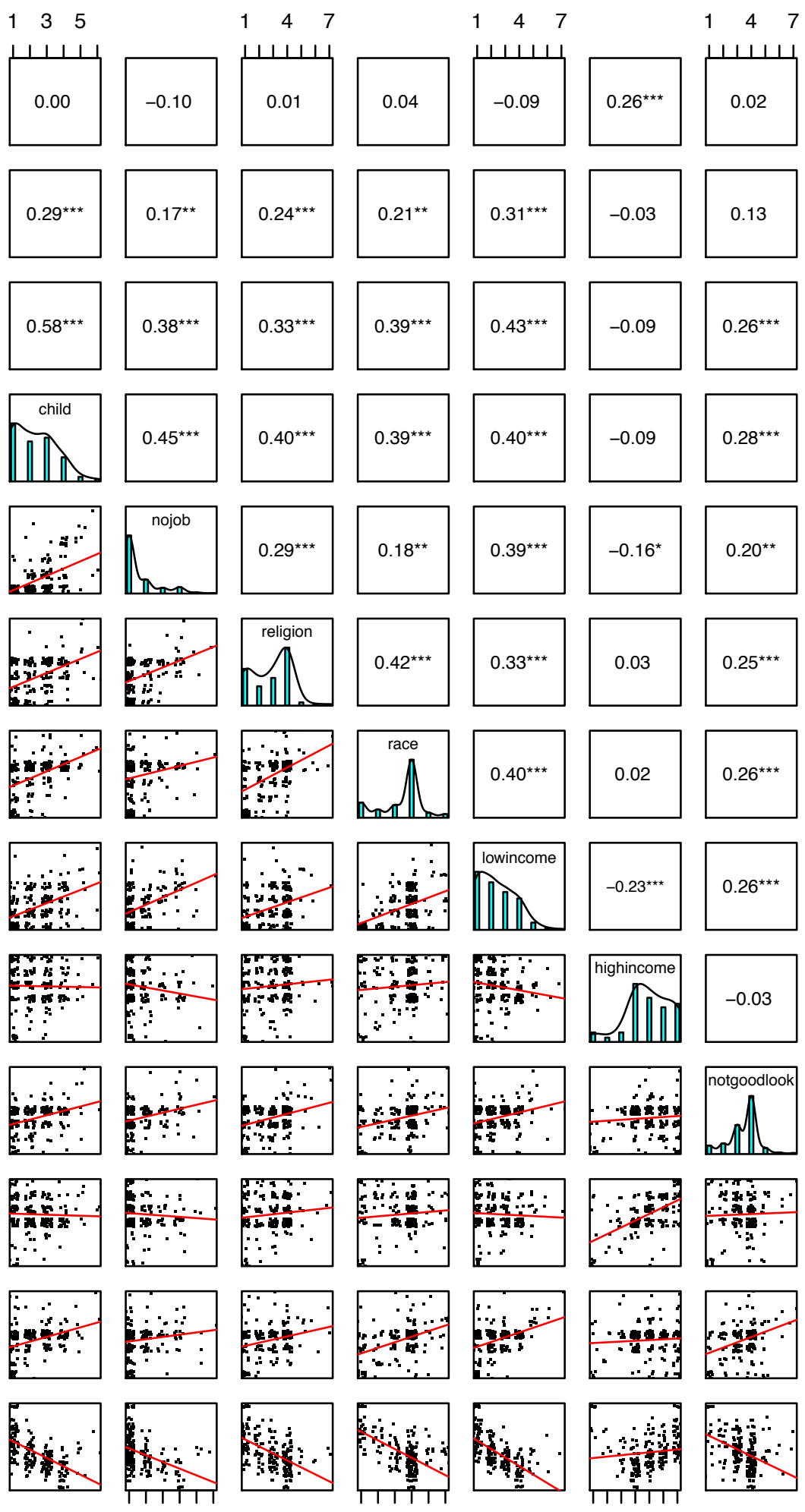
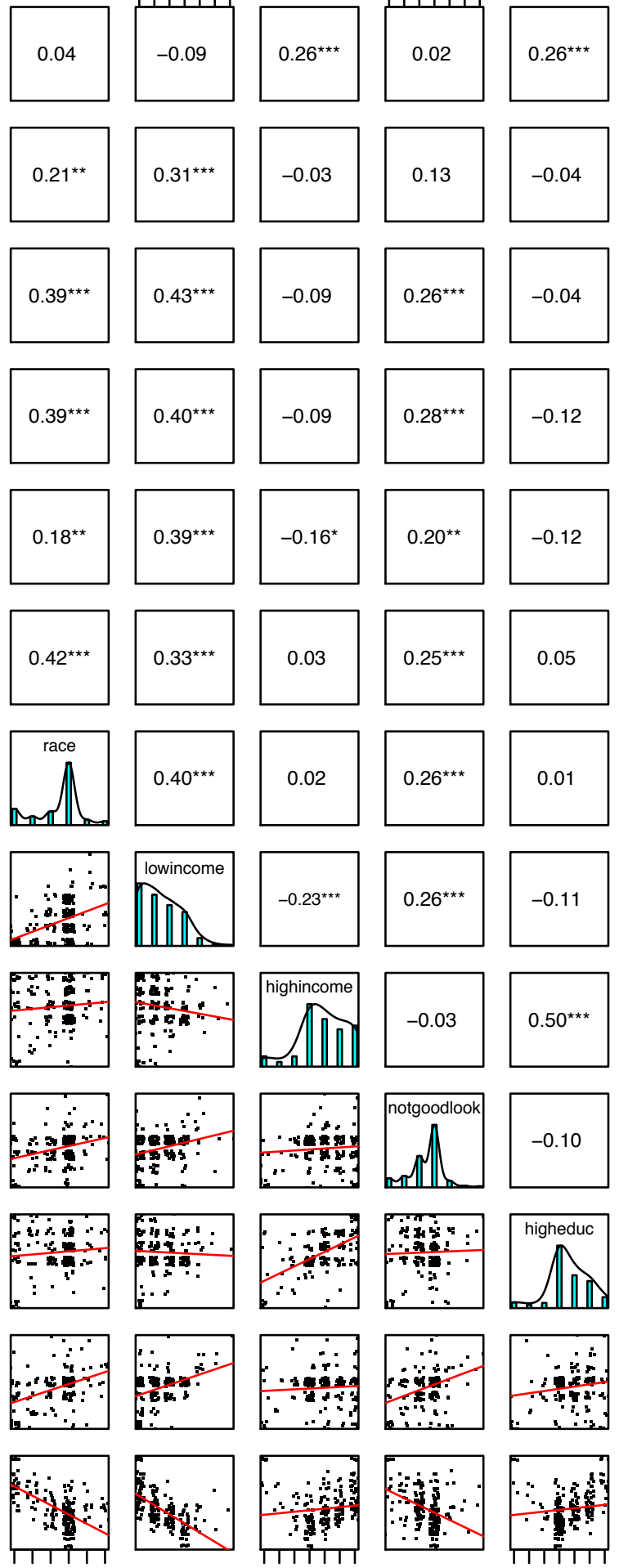

135

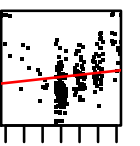

$\begin{array}{lll}1 & 4\end{array}$

$\begin{array}{lll}1 & 4 & 7\end{array}$
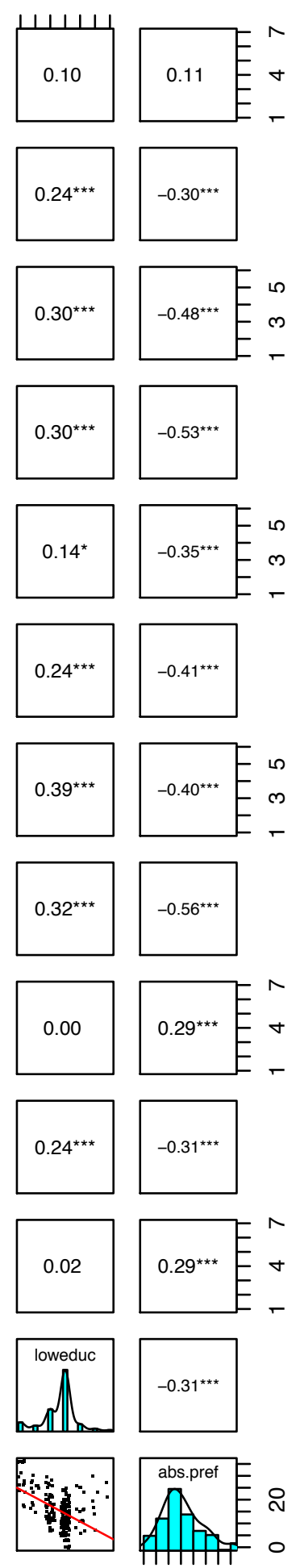

020 
Study 2, All

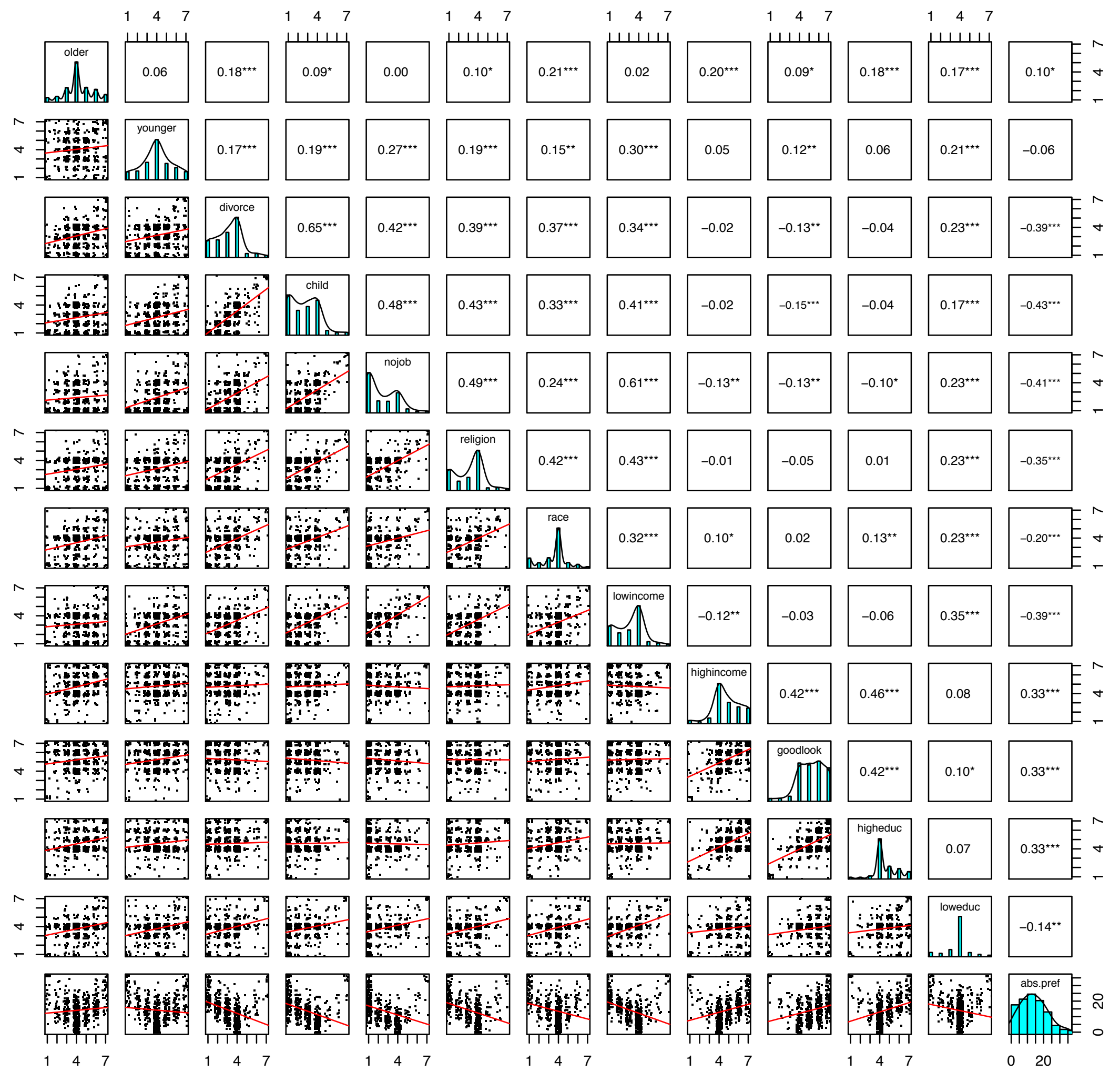




\section{Study 2, Male}

$\begin{array}{lll}1 \quad 4 & 7\end{array}$

$0.16^{*}$

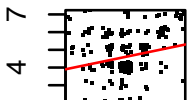

- $\mathrm{A} \therefore \therefore$.

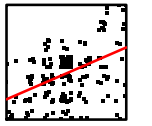

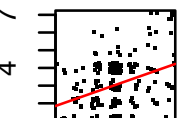
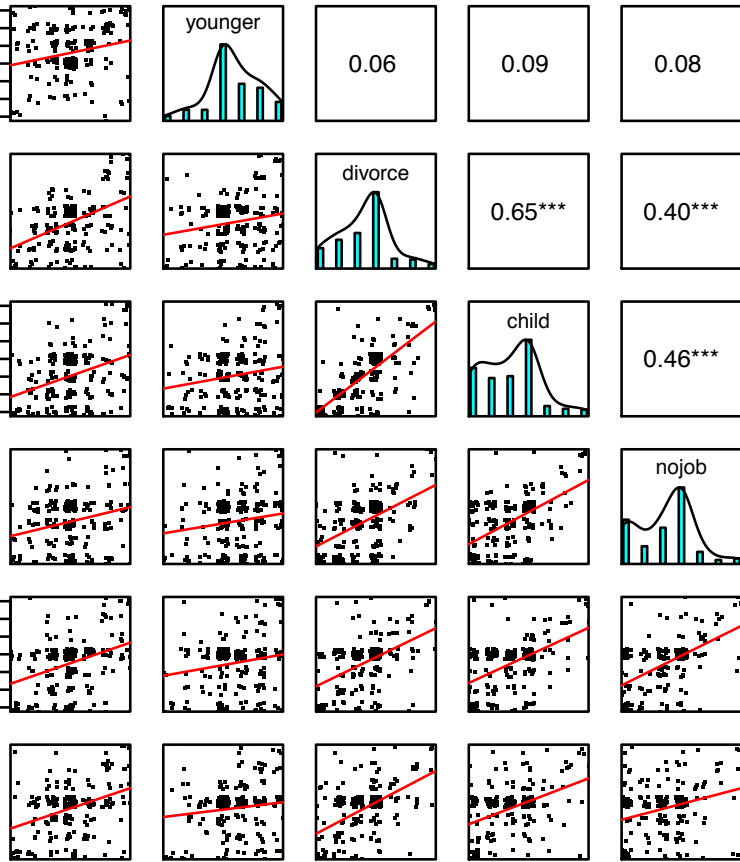

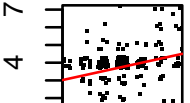
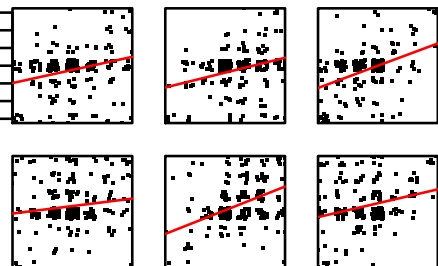

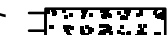

解i

- $\mathrm{A}$. . .
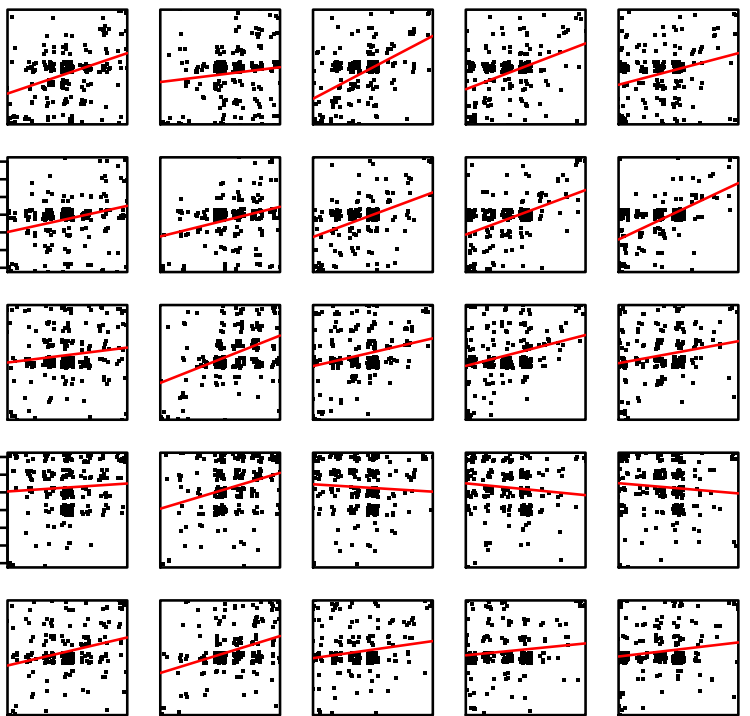

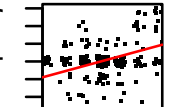
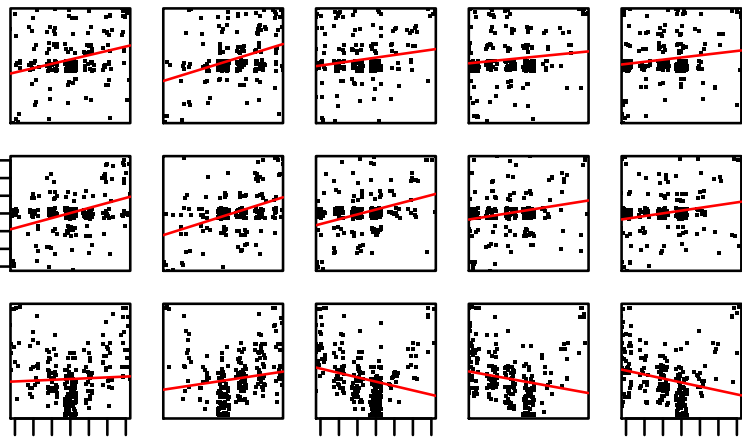

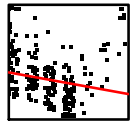

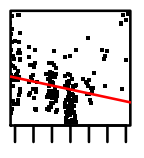

$\begin{array}{lll}14 & 4\end{array}$

$\begin{array}{lll}1 & 4 & 7\end{array}$

$\begin{array}{lll}1 & 4 & 7\end{array}$
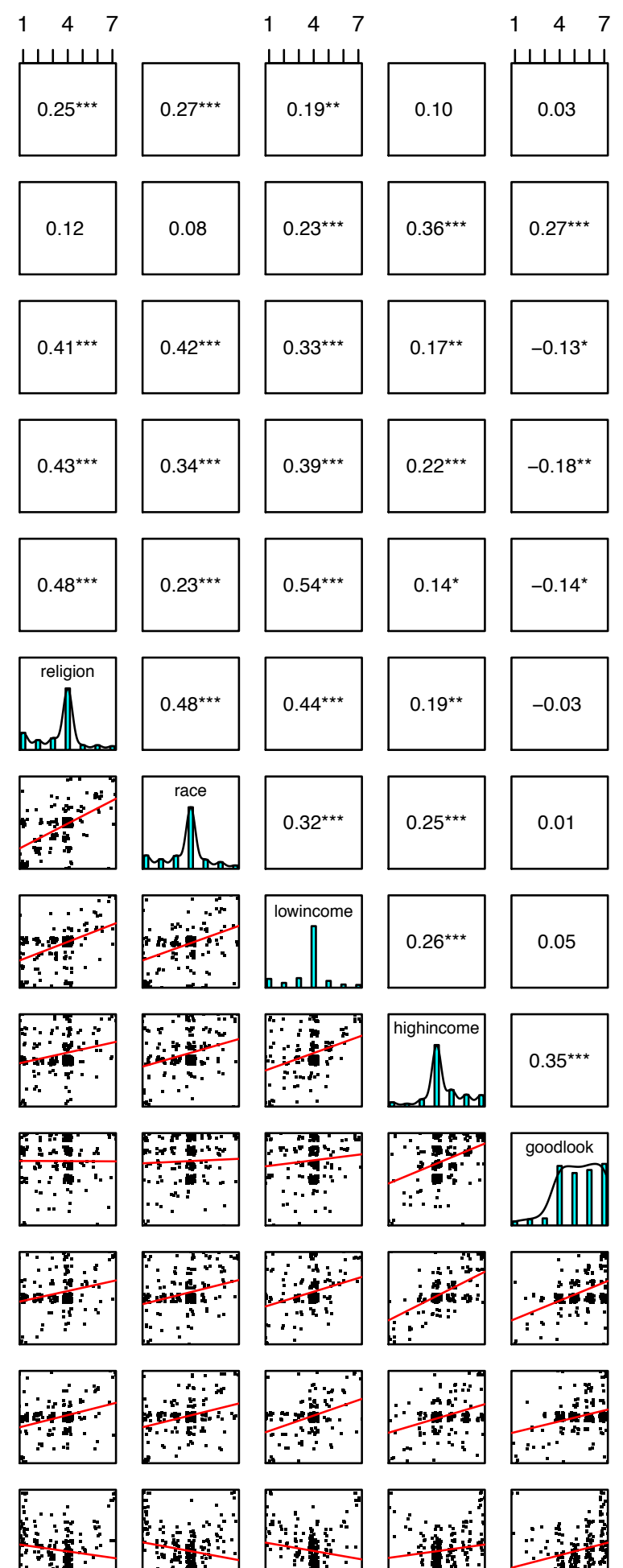
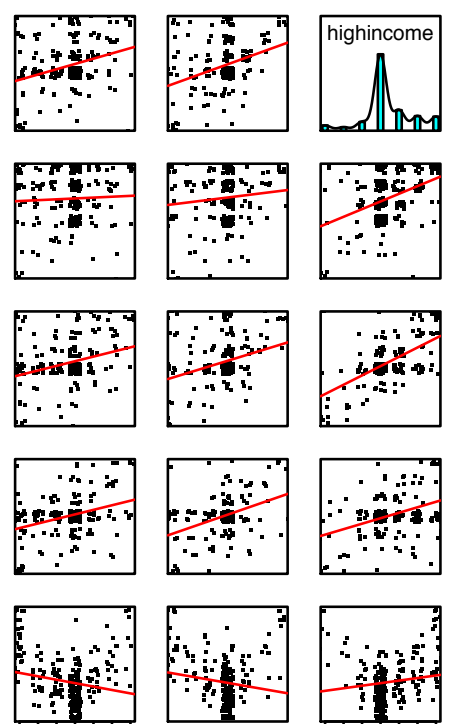

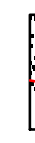
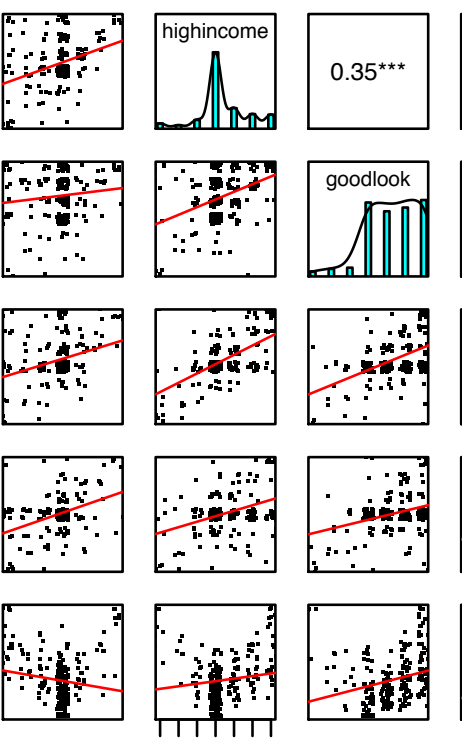

147

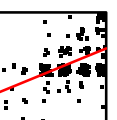

$\begin{array}{lll}1 & 4 & 7\end{array}$
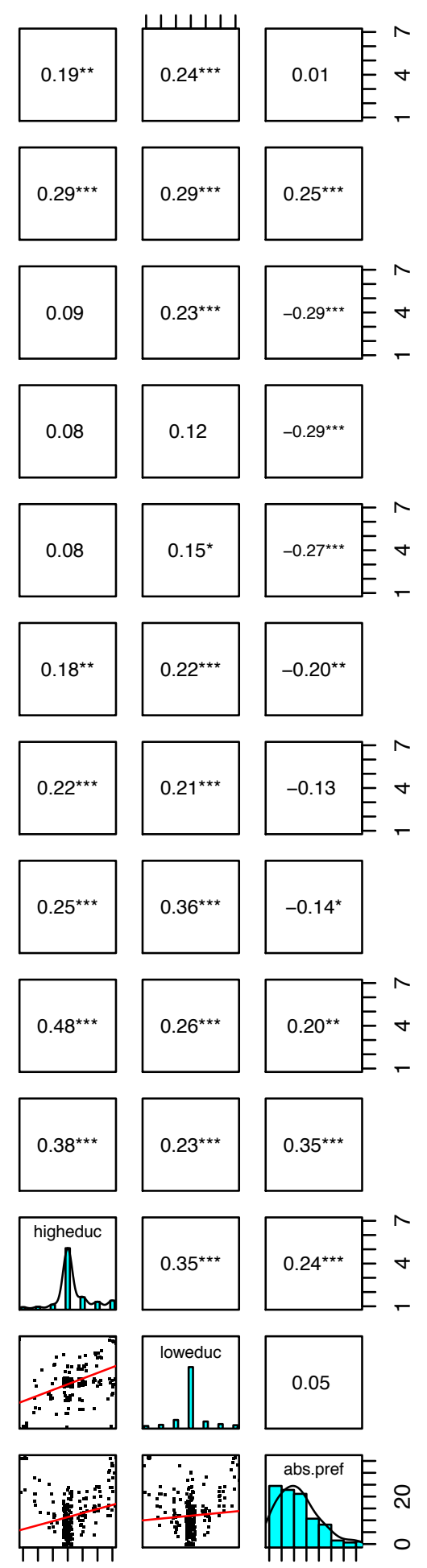

$\begin{array}{lll}1 & 4 & 7\end{array}$

020 


\section{Study 2, Female}

\section{$\begin{array}{lll}1 & 4 & 7\end{array}$

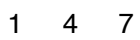

0.05

。

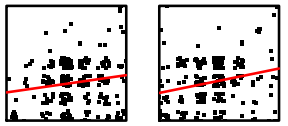

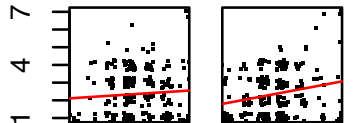

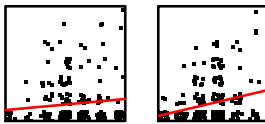

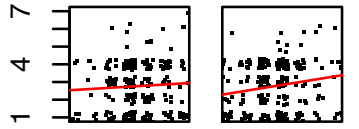

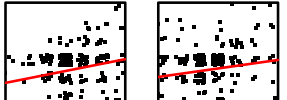

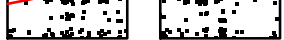

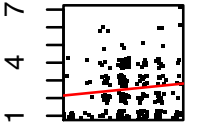

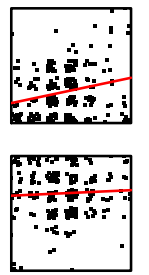

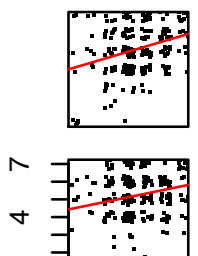

-
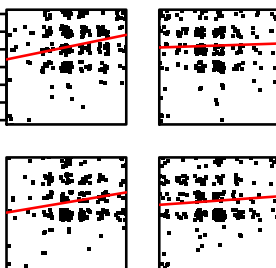

二
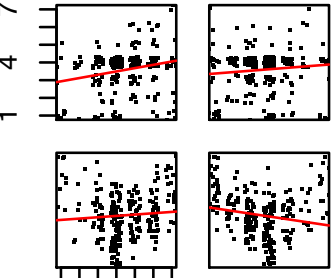
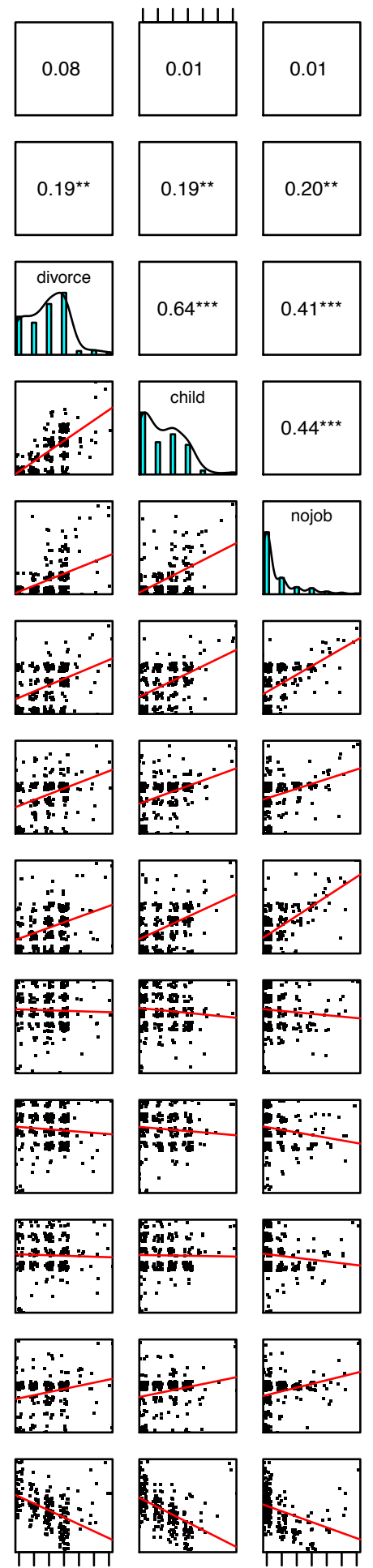
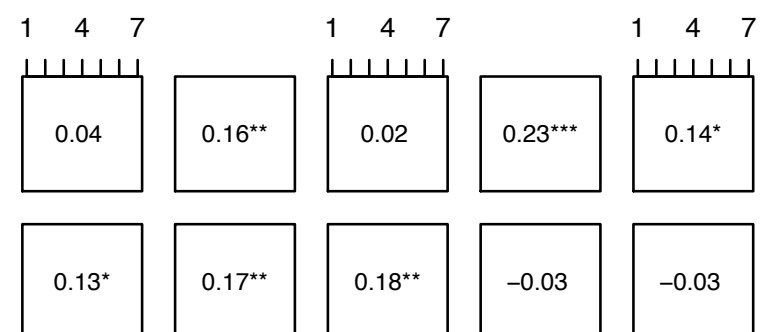

$\begin{array}{lll}1 & 4 & 7\end{array}$

$\begin{array}{lll}1 & 4 & 7\end{array}$
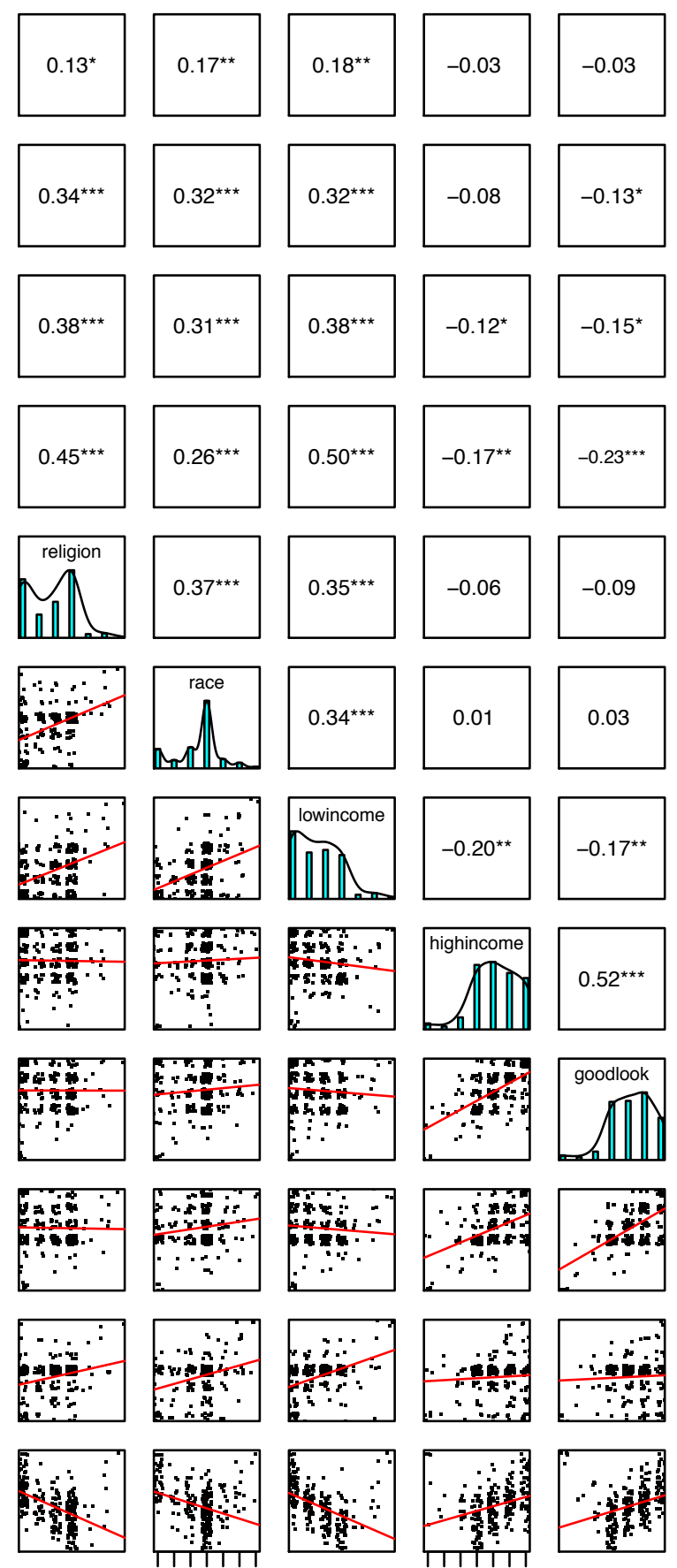
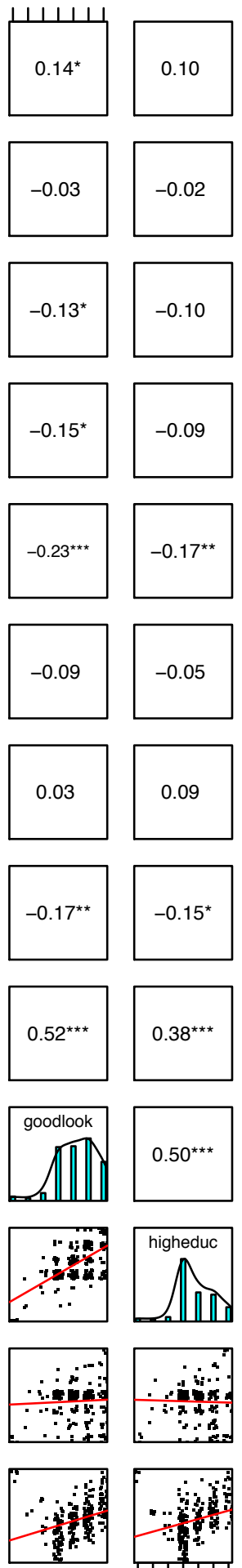

$\begin{array}{lll}1 & 4 & 7\end{array}$
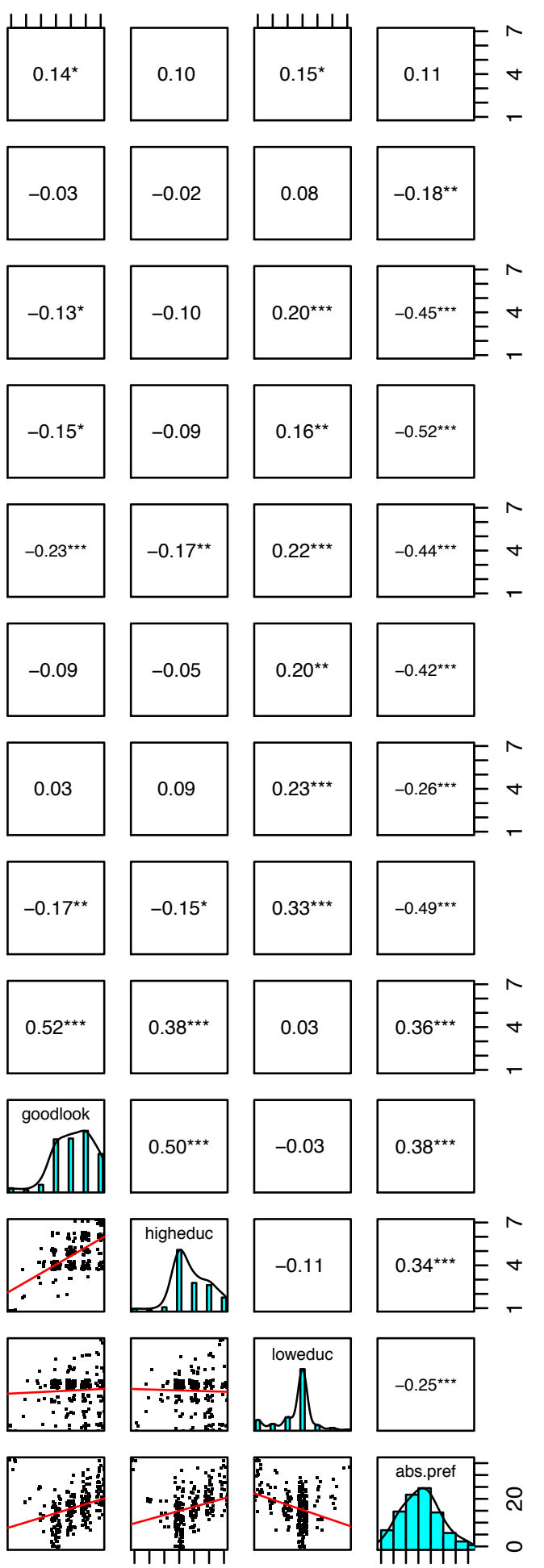

020

$\begin{array}{lllll}1 & 4 & 1 & 4\end{array}$ 